MYKOL ROMERIO
UNIVERSITEASS

\title{
PROBLEMINIAI NEKALTUMO PREZUMPCIJOS ASPEKTAI İODINĖJANT JAUNO PILNAMEČIO NEPAKANKAMĄ SOCIALINĘ BRANDĄ
}

\author{
Dovilè Gaidelytè \\ Mykolo Romerio universiteto Teisès fakulteto \\ Baudžiamosios teisès ir proceso institutas \\ Ateities g. 20, LT-08303 Vilnius, Lietuva \\ Telefonas (+370 5) 2714584 \\ Elektroninis paštas dovile.gaidelyte@gmail.com
}

Pateikta $2013 \mathrm{~m}$. balandžio 15 d., parengta spausdinti $2013 \mathrm{~m}$. liepos $11 \mathrm{~d}$.

doi 10.13165/SMS-13-5-3-15

Anotacija. Nepilnamečio ìtariamojo (kaltinamojo) nepakankama fizine, psichine ir socialine branda suponuoja poreiki užtikrinti efektyvia jo teisiu ir teisetu interesu apsauga viso baudžiamojo proceso metu, taip pat pritaikyti kiek imanoma labiau individualizuota, ¿ nepilnamečio socialine gerove orientuota baudžiamosios atsakomybès forma. Tačiau pasitaiko situaciju, kai ir jaunas pilnametis, jau sulaukęs 18 metu, tačiau nesulaukęs 21 metu, dèl nepakankamos socialinès brandos yra pripažistamas nepilnamečiu; taigi jo atžvilgiu taip pat gali büti taikoma specifine, nepilnamečiams skirta baudžiamosios atsakomybès forma. Šios specifinès nepilnamečiu baudžiamosios atsakomybès formos taikymo galimybe jauniems pilnamečiams lemia tai, kad baudžiamojoje teisejje galiojanti pakankamos socialinès brandos prezumpcija nèra absoliuti, ji gali büti paneigta. Straipsnyje keliamas klausimas, ar de facto šios prezumpcijos paneigimo mechanizmas nèra vienas iš veiksniu, lemiančiu tai, kad Baudžiamojo kodekso 81 straipsnio nuostatos teismu praktikoje taikomos itin vangiai. Tad sio straipsnio tikslas yra aptarti pakankamos socialines brandos prezumpcijos procesinius aspektus, o bütent - koks yra ir koks turètu büti sios prezumpcijos paneigimo mechanizmas. Siekiant šio pagrindinio tikslo, straipsnyje aptariama baudžiamajame procese galiojančiu. 
prezumpciju samprata ir reikšmè, taip pat nekaltumo prezumpcijos svarba paskirstant įrodinejimo pareiga.

Reikšminiai žodžiai: baudžiamasis procesas, socialinè branda, prezumpcija, ịrodinéjimo pareiga, nepilnametis, jaunas pilnametis.

\section{Ivadas}

Lietuvos Respublikos baudžiamajame kodekse ${ }^{1}$ (toliau tekste - ir BK) preziumuojama, kad aštuoniolikos metų sulaukęs asmuo jau yra pakankamai protiškai, socialiai ir fiziškai subrendęs, kad jam galètų būti taikoma suaugusiems skirta baudžiamosios atsakomybès forma. Taigi, būtent nuo aštuoniolikos metų asmuo formaliai pripažistamas suaugusiuoju. Tačiau ši prezumpcija nèra absoliuti; ji gali būti paneigta nustačius, kad jaunuolio ${ }^{2}$ nuo 18 iki 21 metų socialinè branda yra nepakankama pripažinti jị suaugusiuoju. Pagal šiuo metu galiojančias teisès normas ir jų pagrindu susiklosčiusią teismų praktiką, nepakankamos socialinès brandos konstatavimas suponuoja pareigą teismui baudžiamojon atsakomybėn traukiamo jaunuolio atžvilgiu taikyti specifinę nepilnamečių baudžiamosios atsakomybės formą, kuri, kaip žinoma, yra švelnesnė nei suaugusiesiems taikoma baudžiamosios atsakomybės forma ir ja siekiama gerokai daugiau tikslų, susijusių su asmens socialine reabilitacija, nei taikant suaugusiųjų baudžiamosios atsakomybès formą.

Nepakankamos socialinė brandos, kaip kriterijaus specifinei nepilnamečių baudžiamajai atsakomybei taikyti, ịtvirtinimas Lietuvos baudžiamajame ịstatyme neabejotinai vertintinas teigiamai, kadangi, pirma, tokių nuostatų ịtvirtinimas rekomenduojamas daugelyje tarptautinių dokumentų, pavyzdžiui, Jungtinių Tautų standartinėse minimaliose nepilnamečių teisenos igyvendinimo taisyklèse ${ }^{3}$, Europos Tarybos Ministrų Komiteto rekomendacijoje dèl socialinès reakcijos ị nepilnamečių nusikalstamumą ${ }^{4}$, 2003 m. Europos Tarybos Ministrų Komiteto rekomendacijoje Nr. R (2003) $20^{5}$ ir kt.;

1 Lietuvos Respublikos baudžiamasis kodeksas (su vėlesniais pakeitimais ir papildymais). Valstybės žinios. 2000, 89-274.

2 Terminai - jaunas pilnametis, jaunuolis - apibūdinantys asmenis nuo 18 iki 21 metų, tekste bus vartojami kaip sinonimai. Tuo tarpu kalbant apie nepilnamečius, turima omenyje asmenis iki 18 metų.

3 Jungtinių Tautų standartinès minimalios nepilnamečių atžvilgiu vykdomo teisingumo taisyklès (Pekino taisyklès). [interaktyvus]. [žiūrèta 2011-09-25]. <http://www.nplc.lt/nj/Dokumentai/Uzs_teis_aktai/Pekinotaisykles\%20red.htm>.

4 Recommendation No. R (87) 20 of the Committee of Ministers to member states on social reaction to juvenile delinquency. Adopted by the Committee of Ministers on 17 September 1987, at the 410 meeting of the Ministers' Deputies [interaktyvus]. [žiūrèta 2012-12-27]. <https://wcd.coe.int/com.instranet. InstraServlet? command $=$ com. instranet. CmdBlobGet $\&$ InstranetImage $=608029 \&$ SecMode $=1 \&$ DocId $=694$ 290\&Usage $=2>$.

5 Recommendation No. R (2003) 20 of the Committee of Ministers to member states concerning new ways of dealing with juvenile delinquency and the role of juvenile justice. Adopted by the Committee of Ministers on 24 September 2003, at the 853 meeting of the Ministers' Deputies [interaktyvus]. [žiūreta 2012-12-27]. $<$ https://wcd.coe.int/ViewDoc.jsp?id=70063>. 
antra, tokiai teisès aktuose ịtvirtintai galimybei „pratęsti“ nepilnamečių baudžiamosios atsakomybės ypatumų taikymą jauniems pilnamečiams pritaria ir psichologai ${ }^{6}$ bei baudžiamosios teisès mokslininkai ${ }^{7}$. Nepaisant to, Teisès instituto 2010 metais atliktas tyrimas ${ }^{8}$ parodè, kad BK 81 straipsnio 2 dalies nuostatos, reglamentuojančios galimybę taikyti nepilnamečių baudžiamosios atsakomybės ypatumus ir jauniems pilnamečiams nuo 18 iki 21 metų, teismų praktikoje taikomos itin retai. To priežastys minėtame tyrime, taip pat keliuose kituose Lietuvoje atliktuose moksliniuose tyrimuose ${ }^{9}$ iš esmès siejamos su nepakankamai tiksliu įstatymo reguliavimu ir neaiškiais socialinès brandos nustatymo kriterijais. Tačiau iki šiol doktrinoje nebuvo keltas klausimas, ar minėtai problemai įtakos neturi į baudžiamojo proceso reglamentavimo sferą patenkantys aspektai, susiję su pakankamos socialinès brandos prezumpcijos paneigimo mechanizmu.

Taigi šio mokslinio straipsnio tikslas - remiantis baudžiamojo proceso teisès ir kitų teisès šakų doktrina, tarptautiniais ir nacionaliniais teisès aktais, nacionalinių teismų praktika, ịvertinti galiojantị teisinị reguliavimą ir jo pagrindu susiformavusią teisésaugos institucijų subjektų praktiką paneigiant pakankamos socialinès brandos prezumpciją nekaltumo prezumpcijos ir iš jos kylančios įrodinejjimo pareigos paskirstymo taisyklès kontekste bei ịvertinti, kokią ịtaką susiformavusi praktika turi taikant BK 81 straipsnio 2 dalies nuostatas bei užtikrinant nepilnamečiu pripažinto jaunuolio teises ir teisètus interesus baudžiamajame procese. Pastarasis aspektas aktualus tampa turint omenyje tai, kad kai kuriose užsienio valstybėse, pavyzdžiui, Vokietijoje ${ }^{10}$, nepakankamos socialinès brandos nustatymas suponuoja ir specifinių baudžiamojo proceso taisyklių taikymą į baudžiamojo proceso sferą patekusiam jaunuoliui, siekiant kaip įmanoma labiau sumažinti neigiamą baudžiamojo proceso poveiki jaunam asmeniui. Tuo tarpu Lietuvoje nepakankamos socialinès brandos nustatymas yra siejamas vien tik su galimybe taikyti specifinę baudžiamosios atsakomybės formą, nesuteikiant galimybės nepakankamai socialiai brandžiam jaunuoliui užtikrinti papildomas jo procesinių teisių ir teisètų interesų apsaugos garantijas.

Ieškant atsakymų i šiuos klausimus, būtina aptarti ne tik pakankamos socialinès brandos prezumpcijos turinị bei reikšmę, tačiau ir kitų baudžiamajame procese galiojančių prezumpcijų reikšmę baudžiamajam procesui, ypatingą dèmesị skiriant nekal-

6 Žr., pvz., Mathews, B. P. Australian Laws Ascribing Criminal Responsibility to Children: the Implications of an Internal Critique, Postmodern Insights, and A Deconstructive Exploration. Doctor of Philosophy Disertation. Queensland University of Technology, Faculty of Law, 2001.

7 Žr., pvz., Cipriani, D. Children's Rights and the Minimum Age of Criminal Responsibility: A Global Perspective. United Kingdom: Ashgate Publishing, 2009.

8 Nepilnamečių baudžiamosios atsakomybės ypatumų taikymo 18-20 metų jaunuoliams Lietuvoje tyrimas. Tyrimo vadovè Laura Ūselè. Teisès institutas, 2010 [interaktyvus]. [žiūrèta 2012-12-28]. < www.teise.org/ data/Nepilnameciu-baudziamoji-atsakomybe.pdf $>$.

9 Ūselè, L. Socialinès brandos sampratos ir turinio problema sprendžiant jaunų pilnamečių (18-20 metų) baudžiamosios atsakomybès klausimą. Teisè. 2011, 78: 182-195; Ūselè, L. Jaunų pilnamečių (18-20 metų) socialinė branda - nepilnamečių baudžiamosios atsakomybės ypatumų jiems taikymo veiksnys. Teisés problemos. 2010, 2(68): 58-89.

10 Nepilnamečių baudžiamosios atsakomybès ypatumų taikymo 18-20 metų jaunuoliams Lietuvoje tyrimas, supra note 8 . 
tumo prezumpcijai, kuri, kaip matysime, yra bene svarbiausias veiksnys paskirstant įrodinėjimo pareigą baudžiamajame procese.

Atskiri šio mokslinio straipsnio aspektai baudžiamosios teisès ir baudžiamojo proceso doktrinose jau buvo analizuoti. Štai pakankamos socialinès brandos prezumpciją baudžiamosios teisès aspektais moksliniuose darbuose analizavo L. Ūselè ${ }^{11}$, o išsamiausia nepakankamos socialinès brandos kriterijų mokslinė analizė atlikta jau minètame Teisès instituto tyrime. Tam tikrais aspektais jaunų pilnamečių baudžiamosios atsakomybės klausimus analizavo ir R. Ažubalyte் ${ }^{12}$, A. Drakšienè ${ }^{13}$, R. Drakšas ${ }^{14}$, G. Sakalauskas ${ }^{15}$ ir kt. Kalbant apie užsienio valstybių autorius, paminėtini B. P. Mathewso $^{16}$, D. Cipriani ${ }^{17}$, C. Elliotto ${ }^{18}$ moksliniai darbai. Šiame tyrime aptariamos prezumpcijos ir, atskirai, nekaltumo prezumpcija, taip pat ne kartą buvo tapę mokslinès analizès objektu ${ }^{19}$. Nepaisant to, kad esama pirmiau minėtų tyrimų, tenka pripažinti, jog pakankamos socialinès brandos prezumpcijos analizè per nekaltumo prezumpcijos diktuojamos ịrodinèjimo pareigos taisyklès baudžiamajame procese prizmę nei užsienio autorių darbuose, nei Lietuvoje iki šiol atlikta nebuvo. Taigi ir ši aplinkybẻ liudija mokslinio tyrimo aktualumą.

Rašant ši straipsnị daugiausiai taikyti sisteminès analizès, lyginamasis bei teisinių dokumentų analizès metodai. Buvo atliktas kokybinis teismų praktikos tyrimas, kurio metu analizuoti 23 ịvairių instancijų nacionalinių teismų sprendimai (priimti 20062012 metais), kritiniai atvejai, kurie geriausiai iliustruoja straipsnyje keliamų klausimų

11 Ūselè, L. Socialinės brandos sampratos ir turinio problema sprendžiant jaunų pilnamečių (18-20 metų) baudžiamosios atsakomybès klausimą, supra note 9; Ūselè, L. Jaunų pilnamečių (18-20 metų) socialinė branda - nepilnamečių baudžiamosios atsakomybės ypatumų jiems taikymo veiksnys, supra note 9.

12 Ažubalytė, R. Baudžiamojo proceso, kuriame dalyvauja nepilnamečiai, teisinès ir faktinès diferenciacijos prielaidos ir iš jų kylantys reikalavimai. Sąžiningas baudžiamasis procesas. Probleminiai aspektai. Vilnius: Industrus, 2009; Ažubalytė, R; Jurgaitis, R.; Zajančkauskienė, J. Specifinès baudžiamojo proceso rūšys. Vadovèlis. Vilnius: Mykolo Romerio universitetas, 2011.

13 Drakšienè, A. Pakaltinamumas kaip nepilnamečių baudžiamosios atsakomybès prielaida. Teise். 2006, 58: 54-70.

14 Drakšienè, A.; Drakšas, R. Nepilnamečiu baudžiamoji atsakomybè. Vadovèlis. Antroji pataisyta ir papildyta laida. Vilnius: Eugrimas, 2008.

15 Sakalauskas, G. Nepilnamečių baudžiamosios atsakomybės ypatumų, numatytų naujajame Lietuvos Respublikos baudžiamajame kodekse, igyvendinimo problemos. Teisé. 2001, 41: 148-162; Sakalauskas, G.; Jatkevičius, A. Tarptautiniai dokumentai, reglamentuojantys vaikų ir jaunimo baudžiamają atsakomybę. Teisés problemos. 2000, 3-4: 29-39.

16 Mathews, B. P., supra note 6.

17 Cipriani, D., supra note 7.

18 Elliott, C. Criminal Responsibility and Children: A New Defence Required to Acknowledge the Absence of Capacity and Choice. Journal of Criminal Law. 2011, (75): 289-308.

19 Panomariovas, A. Prezumpcija - formalioji ịrodinejimo priemonè (atiduotas leidybai); Rinkevičius, J. Procesiniai ịrodinejjimo baudžiamojoje byloje pagrindai. Vilnius: Vilniaus universiteto leidykla, 1990; Jovaišas, K. Nekaltumo prezumpcija: žinomo principo nežinomi aspektai. Teisés problemos. 2004, 4 (46): 83-99, Goda, G. Nekaltumo prezumpcija: įtvirtinimas Lietuvos teisejje ir kai kurie turinio aspektai. Teisè. 2002, (44): 42-52; Dennis, I. The Law of Evidence. Third Edition. London: Sweet\&Maxwell, 2007; Spencer, M.; Spencer, J. Evidence. Fourth Edition. Great Britain: Ashford Colour Press, 2005; Ashworth, A. Four Threats to the Presumption of Innocence. The International Journal of Evidence \& Proof. 2006, 10: 241-279 ir kt. 
problematiką, taip pat atvejai, patvirtinantys arba paneigiantys keliamas įžvalgas bei diskusinius klausimus. Taigi, priklausomai nuo tyrimo tikslo ir analizuojamos problemos, tyrimo imtis buvo sudaroma remiantis kritinès ir patvirtinančios arba paneigiančios tikslinès imties sudarymo būdais. Taip pat darbe remiamasi Teisès instituto 2010 metais atlikto tyrimo - Nepilnamečių baudžiamosios atsakomybès ypatumų taikymo 18-20 metų jaunuoliams Lietuvoje tyrimas - rezultatais.

\section{Pakankamos socialinės brandos prezumpcija: reikšmė, turinys ir paneigimo mechanizmas de facto}

Kaip jau minèta, baudžiamojoje teisèje galioja prezumpcija, pagal kurią asmens, sulaukusio 18 metų, socialinė branda yra pakankama laikyti ji pilnamečiu bei taikyti jo atžvilgiu suaugusiems skirtas Baudžiamojo įstatymo nuostatas. Kitaip tariant, preziumuojama, kad būtent tokio amžiaus sulaukęs jaunuolis yra pasiekęs visišką emocinę, protinę ir intelektualinę brandą, todèl nuo šio momento, jam padarius nusikalstamą veiką, išnyksta galimybė jo atžvilgiu taikyti specifinę nepilnamečiams skirtą baudžiamosios atsakomybės formą. Tačiau psichologai jau seniai tvirtina, kad kiekvieno asmens, ypatingai vaiko ar jaunuolio, fizinè, kognityvinè, emocinè ir socialinè branda gali skirtis. Todėl tik asmens biologinis amžius nėra pakankamas brandos indikatorius ${ }^{20}$. Psichologai pabrèžia ir tai, kad lygiai kaip paauglystè neprasideda staiga ir netikètai, taip ir brendimas nesibaigia sulaukus tam tikro griežtai apibrěžto amžiaus ${ }^{21}$. Šių mokslininkų mintims pritaria ir teisès tyrinètojai pažymėdami, kad pilnametystè negali būti konstatuojama lyg natūralus reiškinys ar moksliniais tyrimais pagrịstas faktas ${ }^{22}$, todèl kiekvienu atveju, sprendžiant, ar asmuo tiek formaliai, tiek faktiškai yra pasiekęs pilnametystès ribą, būtina ịvertinti jo fizinị bei psichinị išsivystymą, jo socialinę aplinką ir joje igytas vertybes ${ }^{23}$. Neretai pasitaiko atvejų, kai 18 metų sulaukęs asmuo, lyginant jị su bendraamžiais, negali būti pripažįstamas iš tikrujų suaugusiu, o jo branda gali užtrukti dar keletą metų.

Dèl pirmiau nurodytų priežasčių, tarptautiniuose teisės aktuose jaunų pilnamečių baudžiamosios atsakomybès klausimai pradèti akcentuoti jau XX amžiaus pabaigoje Jungtinių Tautų standartinèse minimaliose nepilnamečių teisenos ịgyvendinimo taisyklése ${ }^{24}$ (1985 m.) ir Europos Tarybos Ministrų Komiteto rekomendacijoje dèl socialinès reakcijos į nepilnamečių nusikalstamumą $(1987 \text { m. })^{25}$. Jose rekomenduojama šalių narių vyriausybėms, esant reikalui, peržiūrèti įstatymus, susijusius su jauno amžiaus

20 Mathews, B. P., supra note 6, p. 29.

21 Pradel, J. Lyginamoji baudžiamoji teisè. Vilnius: Eugrimas, 2001, p. 591.

22 Cipriani, D., supra note 7, p. 7.

23 Elliott, C., supra note 18, p. 289-308.

24 Jungtinių Tautų standartinės minimalios nepilnamečių atžvilgiu vykdomo teisingumo taisyklès (Pekino taisykles), supra note 3.

25 Recommendation No. R (87) 20 of the Committee of Ministers to member states on social reaction to juvenile delinquency. Adopted by the Committee of Ministers on 17 September 1987, at the 410 meeting of the Ministers' Deputies, supra note 3. 
pilnamečiais teisès pažeidejjais, kad atitinkami teismai turètų galimybę priimti nuosprendžius, kurie savo prigimtimi yra auklejjamojo pobūdžio ir skatina socialinę integraciją, taip pat stengtis išplėsti nepilnamečiams įtvirtintų principų taikymą ir jauniems pilnamečiams teisès pažeidejjams ${ }^{26}$.

Atsižvelgdamos ị šias tarptautinių teisès aktų rekomendacijas, daugelis valstybių (Vokietija, Nyderlandai, Austrija, Rusija, Lenkija ir kt. ${ }^{27}$ ) savo nacionaliniuose įstatymuose įtvirtino galimybę taikyti nepilnamečiu specifinę baudžiamosios atsakomybès formą ir jauniems pilnamečiams. I minètas rekomendacijas ịsiklausè ir Lietuvos ịstatymų leidejjas, Baudžiamojo kodekso 81 straipsnyje ịtvirtindamas galimybę taikyti specifinę baudžiamosios atsakomybès formą ne tik nepilnamečiams iki aštuoniolikos metų, bet ir jaunuoliams nuo 18 iki 21 metų amžiaus. Pagal šio straipsnio 2 dalį, nepilnamečių baudžiamosios atsakomybės ypatumai, įtvirtinti BK XI skyriuje, gali būti taikomi ir asmeniui, kuriam nusikalstamos veikos padarymo metu buvo sueję 18 metų, tačiau nebuvo suejję 21 metai, jeigu teismas, atsižvelgęs ị padarytos nusikalstamos veikos pobūdį, motyvus bei kitas bylos aplinkybes, o prireikus - į specialisto paaiškinimus ar išvadą, nusprendžia, kad toks asmuo pagal socialinę brandą prilygsta nepilnamečiui ir baudžiamosios atsakomybės ypatumų taikymas jam atitiktų Baudžiamojo kodekso 80 straipsnyje numatytą nepilnamečių baudžiamosios atsakomybės paskirtį.

Taigi, galima skirti šiuos pagrindinius aspektus, reikšmingus BK 81 straipsnio nuostatų taikymui: diskrecinę teisę nuspręsti, ar jaunuolio nuo 18 iki 21 metų socialinè branda nèra pakankama taikyti jam suaugusių asmenų baudžiamosios atsakomybès nuostatas, turi išimtinai bylą nagrinėjantis teismas ir šią aplinkybę konstatuoja priimdamas galutinị teismo procesinį dokumentą; nepakankama socialinè branda nustatoma ịvertinus dvejopo pobūdžio aplinkybes - byloje surinktais duomenimis nustatytas jaunuoliui inkriminuojamos nusikalstamos veikos padarymo aplinkybes (nusikalstamos veikos dalykas, jos padarymo būdas, įrankiai, priemonès, laikas, vieta, tikslas ir pan. ${ }^{28}$ ) ir tam tikrais atvejais išklausius specialisto paaiškinimų arba ịvertinus jo pateiktą išvadą. Teismų praktikoje sprendžiant klausimą dèl jaunuolio pakankamos socialinès brandos vertinamos dar ir kitokio pobūdžio aplinkybės - kaltinamojo (nuteistojo) elgesys baudžiamojo proceso metu (pavyzdžiui, jo duodamų parodymų išsamumas, turinys, motyvai, dèl kurių jis atsisako duoti parodymus, ir pan. ${ }^{29}$, kaltinamojo (nuteistojo) sveikatos būklę apibūdinančios aplinkybès ${ }^{30}$, jo asmenybę charakterizuojantys duomenys ${ }^{31}$.

26 Nepilnamečiu baudžiamosios atsakomybès ypatumu taikymo 18-20 metu jaunuoliams Lietuvoje tyrimas, supra note 8.

27 Ibid., p. 15.

28 Abramavičius, A., et al. Lietuvos Respublikos baudžiamojo kodekso komentaras. Bendroji dalis. Vilnius: Teisinès informacijos centras, 2004, p. 435.

29 Žr., pvz., Šakių rajono apylinkès teismo 2008 m. spalio 27 d. nuosprendis baudžiamojoje byloje Nr. 1-64634/2008.

30 Žr., pvz., Vilniaus apygardos teismo $2007 \mathrm{~m}$. gruodžio 3 d. nuosprendis baudžiamojoje byloje Nr. 1-208/2007.

31 Žr., pvz., Kauno apygardos teismo 2010 m. gruodžio 7 d. nuosprendis baudžiamojoje byloje Nr. 1A-759397/10; Klaipèdos apygardos teismo 2009 m. gegužès 28 d. nutartis baudžiamojoje byloje Nr. 1A-248458/2009; Lietuvos Aukščiausiojo Teismo Baudžiamujų bylų skyriaus teisejjų kolegijos 2009 m. vasario 3 d. nutartis baudžiamojoje byloje Nr. 2K-39/2009 ir kt. 
Nepaisant galiojančiame BK ịtvirtinto modernaus jaunų pilnamečių instituto, kaip parodè Teisès instituto atliktas tyrimas, ji reglamentuojančios nuostatos praktikoje taikomos itin retai ${ }^{32}$. To priežastys aiškinamos įvairiai. Minètame tyrime nurodoma, kad vangų BK 81 straipsnio 2 dalies nuostatų taikymą lemia keletas aplinkybių: pirma, istatyme nekonkretizuota, kaip turi būti suprantamas ,socialinès brandos“ terminas ir nèra ịteisintos socialinès brandos nustatymo metodikos, neapibrèžti kriterijai; antra, nėra ir specialistų, kurie padètų ịvertinti jauno pilnamečio socialinę brandą ${ }^{33}$. Baudžiamosios teisès mokslininkai retą BK 81 straipsnio 2 dalies nuostatų taikymą praktikoje sieja su tuo, kad kriterijai, lemiantys šių nuostatų taikymą, yra vertinamojo pobūdžio ${ }^{34}$. Be šiu pirmiau nurodytų priežasčiu, manytina, kad BK 81 straipsnio 2 dalyje įtvirtintų nuostatų mažą populiarumą teismų praktikoje lemia dar ir kitos aplinkybès.

Teismų praktikos analizė leidžia daryti išvadą, kad tiek teismai, tiek prokurorai ir advokatai nepakankamos socialinès brandos nustatymo faktą sieja išimtinai tik su galimybe sušvelninti kaltinamajam skirtiną bausmę. Šią išvadą patvirtina teismų praktikoje pastebètos tendencijos, kad BK 81 straipsnio 2 dalies norma remiasi kaltinamieji ir jų gynèjai, prašydami skirti švelnesnę bausmę pirmosios instancijos teisme, taip pat paprastai šis BK straipsnis, jo netaikymo ar netinkamo taikymo klausimas tampa apeliacinio ar kasacinio skundo dalyku. Be to, atsižvelgiant ị tai, kad BK 81 straipsnio 2 dalies taikymas yra išimtinè bylą nagrinèjančio teismo diskrecinè teisè, nepakankamos socialinès brandos įrodinèjimas vyksta išimtinai tik teisminio bylos nagrinèjimo stadijoje. Esant pirmiau nurodytoms aplinkybėms, kyla pagrịstas klausimas, kam gi praktiškai tenka pareiga pateikti duomenis, paneigiančius pakankamos socialinės brandos prezumpciją?

Jau minètame Teisès instituto atliktame tyrime nustatyta, kad nuo $2005 \mathrm{~m}$. sausio 1 d. iki 2009 m. gruodžio 31 d. BK 81 straipsnio 2 dalies nuostatų taikymo klausimas Lietuvoje išnagrinètose baudžiamosiose bylose buvo iškeltas tik 36 atvejais, iš jų tik 8 bylose šios nuostatos buvo taikytos. Tyrëjai nustate, kad tik porą kartų tarp tirtų atvejų BK 81 straipsnio 2 dalies taikymo klausimą nagrinėdamas baudžiamają bylą teismas iškèlè savo iniciatyva, visais kitais atvejais šią aplinkybę teigè gynybos pusé, pateikdama tai patvirtinančius duomenis ${ }^{35}$.

Rengiant ši mokslinį straipsnị, buvo atliktas kokybinio pobūdžio teismų praktikos tyrimas, kurio metu buvo išanalizuota 23 ịvairių instancijų Lietuvos Respublikos teismų sprendimų, priimtų 2006-2012 metais ${ }^{36}$, kuriuose buvo keliamas BK 81 straipsnio

32 Nepilnamečių baudžiamosios atsakomybès ypatumu taikymo 18-20 metu jaunuoliams Lietuvoje tyrimas, supra note 8, p. 15.

33 Ibid., p. 15.

34 Ūselè, L., supra note 9.

35 Nepilnamečiu baudžiamosios atsakomybès ypatumų taikymo 18-20 metu jaunuoliams Lietuvoje tyrimas, supra note 8 , p. 15.

36 Utenos rajono apylinkès teismo $2011 \mathrm{~m}$. kovo $1 \mathrm{~d}$. nuosprendis baudžiamojoje byloje Nr. 1-23-373/2011; Joniškio rajono apylinkès teismo $2011 \mathrm{~m}$. lapkričio $18 \mathrm{~d}$. nuosprendis baudžiamojoje byloje Nr. 1-13645/2011; Kauno apygardos teismo 2009 m. gruodžio 23 d. nuosprendis baudžiamojoje byloje Nr. 1-76290/09; Vilniaus rajono apylinkès teismo 2012 m. kovo 7 d. nuosprendis baudžiamojoje byloje Nr. 1-58269/2012; Kauno miesto apylinkès teismo 2011 m. balandžio 15 d. nuosprendis baudžiamojoje byloje 
2 dalies nuostatų taikymo jauniems pilnamečiams klausimas. Atlikus tyrimą nustatyta, kad dvidešimt vienoje baudžiamojoje byloje klausimą dėl teisiamojo nepakankamos socialinès brandos iškèlè būtent gynybos pusè ir tik dviem atvejais ${ }^{37}$ ši klausimą savo iniciatyva èmèsi spręsti bylą nagrinèjęs teismas. Atlikus ši tyrimą nustatyta ir tai, kad kaltinamasis ir (ar) jo gynejjas, išsakydami teismui abejones dẻl nepakankamos socialinès brandos, daugeliu atveju pateikè savo iniciatyva surinktus duomenis - medicininius dokumentus, asmenị charakterizuojančius duomenis ${ }^{38} \mathrm{ir}$, daug rečiau, privačių ekspertų ar asmenų, turinčių specialių žinių, pateiktas konsultacines išvadas ${ }^{39}$. Gynybos pusè,

Nr. 1-129-651/2011; Vilniaus apygardos teismo $2010 \mathrm{~m}$. sausio $25 \mathrm{~d}$. nuosprendis baudžiamojoje byloje Nr. 1A-123/2010; Vilniaus apygardos teismo 2007 m. gruodžio 3 d. nuosprendis baudžiamojoje byloje Nr. 1-208/2007; Kauno apygardos teismo $2011 \mathrm{~m}$. balandžio 22 d. nutartis baudžiamojoje byloje Nr. 1A-276-317/2011; Kauno apygardos teismo 2010 m. gruodžio 7 d. nuosprendis baudžiamojoje byloje Nr. 1A-759-397/2010; Šiaulių apygardos teismo 2011 m. gegužès 5 d. nuosprendis baudžiamojoje byloje Nr. 1A-48-135/2011; Klaipèdos apygardos teismo 2009 m. gegužès 28 d. nutartis baudžiamojoje byloje Nr. 1A-248-458/2009; Klaipèdos apygardos teismo $2012 \mathrm{~m}$. balandžio 23 d. nuosprendis baudžiamojoje byloje Nr. 1A-99-557/2009; Lietuvos apeliacinio teismo Baudžiamujų bylų skyriaus teisėjų kolegijos 2011 m. liepos 15 d. nutartis baudžiamojoje byloje Nr. 1A-110/2011; Lietuvos apeliacinio teismo Baudžiamuju bylų skyriaus teisejjų kolegijos 2012 m. balandžio 27 d. nutartis baudžiamojoje byloje Nr. 1A-216/2012; Lietuvos Aukščiausiojo Teismo Baudžiamujų bylų skyriaus teisèjų kolegijos $2011 \mathrm{~m}$. birželio 30 d. nutartis baudžiamojoje byloje Nr. 2K-325/2011; Lietuvos Aukščiausiojo Teismo Baudžiamujjų bylų skyriaus teisèjų kolegijos 2011 m. gruodžio 27 d. nutartis baudžiamojoje byloje Nr. 2K-629/2011; Lietuvos Aukščiausiojo teismo Baudžiamujų bylų skyriaus teisèjų kolegijos $2009 \mathrm{~m}$. vasario $3 \mathrm{~d}$. nutartis baudžiamojoje byloje Nr. 2K-39/2009; Lietuvos Aukščiausiojo Teismo Baudžiamujų bylų skyriaus teisejų kolegijos 2009 m. vasario 3 d. nutartis baudžiamojoje byloje Nr. 2K-39/2009; Lietuvos Aukščiausiojo Teismo Baudžiamuju bylų skyriaus teisèjų kolegijos 2008 m. gruodžio 22 d. nutartis baudžiamojoje byloje Nr. 2K-435/2008; Lietuvos Aukščiausiojo Teismo Baudžiamujų bylų skyriaus teisèjų kolegijos 2006 m. birželio 13 d. nutartis baudžiamojoje byloje Nr. 2K-418/2006; Lietuvos Aukščiausiojo Teismo Baudžiamujjų bylų skyriaus teisèjų kolegijos 2005 m. kovo 8 d. nutartis baudžiamojoje byloje 2K- 67/2005; Lietuvos Aukščiausiojo Teismo Baudžiamujjų bylų skyriaus teisèjų kolegijos $2006 \mathrm{~m}$. vasario $7 \mathrm{~d}$. nutartis baudžiamojoje byloje Nr. 2K-142/2006; Lietuvos Aukščiausiojo Teismo Baudžiamujų bylų skyriaus teisèjų kolegijos 2006 m. balandžio 25 d. nutartis baudžiamojoje byloje Nr. 2K-266/2006.

37 Abu šie atvejai išsiskyre iš kitu analizuotų atvejų. Antai, Kauno miesto apylinkès teismo išnagrinètoje byloje teisiamajam buvo diagnozuotas objektyviai pasireiškiantis sveikatos sutrikimas - ūgio deficitas, žemaūgiškumas. Todèl bylą nagrinėjęs teismas, pastebejęę defektus, pats ėmèsi priemonių surinkti duomenis apie kaltinamojo socialinę brandą - iškvietè ir teisiamajame posėdyje apklausė jo motiną, išsireikalavo iš gydymo ịstaigų su teisiamojo sveikata susijusius medicininius dokumentus bei paskyré atlikti teismo psichiatrijos, psichologijos ekspertizę (Kauno miesto apylinkès teismo $2011 \mathrm{~m}$. balandžio 15 d. nuosprendis baudžiamojoje byloje Nr. 1-129-651/2011). Vilniaus apygardos teismas, nagrinėdamas baudžiamają bylą, savo iniciatyva iškèlè klausimą dèl vieno iš teisiamujų nepakankamos socialinès brandos, kadangi ikiteisminio tyrimo metu, iškilus abejonių dèl jo pakaltinamumo, buvo renkami duomenys apie psichinę sveikatą. Iš šių medicininių duomenų matyti, kad teisiamasis V. D. buvo ne kartą gydytas psichiatrinèje ligoninejje, jam diagnozuotos ịvairios psichinès ligos - oligofrenija, debilumo laipsnis su hiperdinaminiu ir epilepsiniu sindromu su bendros kalbos neišsivystymu. Šie duomenys bylą išnagrinejjusiam teismui ir sukèle abejonių dèl kaltinamojo nepakankamos socialinès brandos (Vilniaus apygardos teismo $2007 \mathrm{~m}$. gruodžio $3 \mathrm{~d}$. nuosprendis baudžiamojoje byloje Nr. 1-208/2007).

38 Žr., pvz., Utenos rajono apylinkès teismo $2011 \mathrm{~m}$. kovo $1 \mathrm{~d}$. nuosprendis baudžiamojoje byloje Nr. 1-23373/2011, Joniškio rajono apylinkès teismo $2011 \mathrm{~m}$. lapkričio 18 d. nuosprendis baudžiamojoje byloje Nr. 1-13-645/2011 ir kt.

39 Žr., pvz., Lietuvos Aukščiausiojo Teismo Baudžiamujų bylų skyriaus teisėjų kolegijos 2009 m. vasario 3 d. nutartis baudžiamojoje byloje Nr. 2K-39/2009; Šiaulių apygardos teismo Šiaulių apygardos teismo 2011 m. gegužès 5 d. nuosprendis baudžiamojoje byloje Nr. 1A-48-135/2011. 
pateikdama teismui minètus duomenis, visais atvejais prašè skirti teismo medicinos psichiatrijos, psichologijos ekspertizę. Toks prašymas buvo patenkintas trijose bylose, dar dviejose bylose nutarta teismo posėdyje apklausti specialistus - psichologus ir (ar) psichiatrus. Kitais atvejais tokie gynybos prašymai, iš esmės nepateikiant jokių svarių motyvų, buvo atmesti. Čia ịdomu ir tai, kad kaltinimo pusè nè vienoje byloje nepalaikè gynybos prašymo patikrinti kylančias abejones dèl kaltinamojo socialinès brandos, net ir tais atvejais, kai teismo nuosprendžiu buvo taikytos BK 81 straipsnio 2 dalies nuostatos. Šios aplinkybès patvirtina prieš tai išsakytą mintị, kad teismai ir prokurorai šios normos taikymą sieja išimtinai tik su baudžiamosios atsakomybės švelninimu, todèl ir i prašymus ją taikyti žvelgia itin skeptiškai.

Analizuojant teismų nuosprendžių ar nutarčių motyvuojamąsias dalis, matyti, kad, atsisakant taikyti BK 81 straipsnio 2 dalies nuostatas, pagrindiniu motyvu nurodoma tai, jog bylos medžiagoje nėra objektyvių duomenų, leidžiančių abejoti kaltinamojo ar nuteistojo socialine branda. Pavyzdžiui, Lietuvos Aukščiausiasis Teismas, atmesdamas nuteistujų kasacinius skundus, nurodo, kad, ,byloje néra duomenu apie nuteistojo psichinès veiklos sutrikimus ar nepakankama jo fizinę ir psichinę branda, t. y. kad jis nesugebètu vertinti visuomenés keliamy reikalavimu, numatyti savo veikos padariniu, negalètu kontroliuoti savo veiksmu kritinése situacijose ${ }^{640}$; ,Byloje tokiu duomenu, kurie leistų teigti, kad $R$. C. turimos žinios ar socialiniai igūdžiai buvo nepakankami,

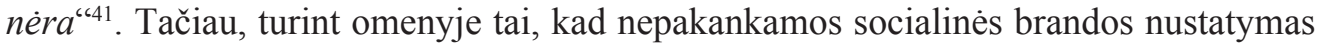
yra teismo diskrecinė teisè, o šios aplinkybès įrodinëjimas vyksta išimtinai teisminio nagrinėjimo metu, vertinant tokius teismų motyvus lieka neaišku, kas gi turètų rinkti ir i baudžiamają bylą pateikti duomenis, patvirtinančius arba paneigiančius nepakankamą kaltinamojo ar nuteistojo socialinę brandą. Pasitaikè ir atvejų, kai teismai tiesiogiai nurodo, jog tokius duomenis turi pateikti teigianti, t. y. gynybos, pusé, o šiai to nepadarius, nèra pagrindo ir svarstyti klausimo dèl BK 81 straipsnio 2 dalies nuostatų taikymo. Antai, Lietuvos apeliacinis teismas vienoje byloje nurodè, kad,Apeliacinés instancijos teismas nemato jokio pagrindo nuteistojo A. M. atžvilgiu taikyti Lietuvos Respublikos BK XI skyriaus nuostatu. Apeliaciniame skunde nurodoma, kad A. M. nusikalstamos veikos padarymo metu pagal socialine branda prilygo nepilnamečiui, tačiau byloje nepateikta objektyviu duomenu, patvirtinančių ši teiginį ${ }^{642}$.

Tai, kad nepakankamos socialinès brandos nustatymas ir pripažinimas yra būtent gynybos „rankose“, patvirtina ir teismų praktikoje pasitaikantys atvejai, kai pirmosios instancijos teisme gynybos pusei iškèlus abejonių dèl nepakankamos kaltinamojo socialinès brandos, nei teismas, nei prokuroras nesiima priemonių šioms abejonèms patikrinti. Tuo tarpu nagrinėjant bylą apeliacinès instancijos teisme, nuteistajam pateikus privataus eksperto konsultacinę išvadą, aukštesnès instancijos teismas pripažįsta, jog

40 Lietuvos Aukščiausiojo Teismo Baudžiamujų bylų skyriaus teisẻjų kolegijos $2006 \mathrm{~m}$. birželio 13 d. nutartis baudžiamojoje byloje Nr. 2K-418/2006.

41 Lietuvos Aukščiausiojo Teismo Baudžiamųų bylų skyriaus teisèjų kolegijos $2011 \mathrm{~m}$. birželio $30 \mathrm{~d}$. nutartis baudžiamojoje byloje Nr. 2K-325/2011.

42 Lietuvos apeliacinio teismo Baudžiamujų bylų skyriaus teisejų kolegijos $2012 \mathrm{~m}$. balandžio $27 \mathrm{~d}$. nutartis baudžiamojoje byloje Nr. 1A-216/2012. 
pirmosios instancijos teismas BK 81 straipsnio 2 dalies nuostatų nuteistojo atžvilgiu netaikè nepagrįstai43.

Pirmiau aptarti teismų praktikos pavyzdžiai ir atliktų tyrimų metu gauti rezultatai leidžia daryti pagrịstą išvadą, kad pagal šiuo metu susiklosčiusią teismų praktiką, pareiga pateikti įtikinamų duomenų, paneigiančių teisiamo jauno pilnamečio socialinę brandą, de facto tenka būtent gynybos pusei. Tokia išvada tiesiogiai suponuoja kitą probleminį aspektą - ar susiklosčiusi teismų praktika yra pateisinama bendrajame baudžiamajame procese galiojančios įrodinèjimo pareigos paskirstymo taisyklès bei nepilnamečių ${ }^{44}$ baudžiamajam procesui keliamų specifinių tikslų kontekste. Norédami atsakyti ị ši klausimą, panagrinèkime, kas gi yra prezumpcijos, kokias funkcijas jos atlieka ir kam gi tenka jų paneigimo pareiga baudžiamajame procese.

\section{Prezumpcijos ir įrodinëjimo pareiga baudžiamajame procese}

Terminas „prezumpcija“ yra kilęs iš lotynų kalbos žodžio „praesumptio“, reiškiančio prielaidą, spèjimą, išankstinę nuomonę, užbėgimą už akiự ${ }^{45}$. Todèl kalbant abstrakčiai, teisès doktrinoje prezumpcijos suprantamos kaip tam tikros prielaidos, faktai, nereikalaujantys papildomo įrodinèjimo, kurie laikomi tikrais (egzistuojančiais), kol neįrodyta priešingai.

Baudžiamojo proceso teisès doktrinoje, skirtingai nei, pavyzdžiui, civilinio proceso doktrinoje ${ }^{46}$, prezumpcijos apibūdinamos kaip prielaidos, pagrịstos tikimybe; jos atspindi pastovius, daug kartų stebėtus faktų, ivvykių, reiškinių ar atskirų jų savybių ryšius $^{47}$. A. Panomariovas, papildydamas ši prezumpcijų apibrèžimą nurodo dar ir tai, kad kalbant apie prezumpcijas, termino ,prielaida“ vartojimas yra netikslus. Todèl, anot šio autoriaus, teisingiau būtų sakyti, kad prezumpcija - tai statistiškai grindžiamas numa-

43 Pavyzdžiui, Šiaulių apygardos teismas, išnagrinejęs baudžiamają bylą pagal nuteistojo apeliacinị skundą, $2011 \mathrm{~m}$. gegužès 5 d. nuosprendžiu pakeitè Telšių rajono apylinkès teismo $2009 \mathrm{~m}$. gruodžio $22 \mathrm{~d}$. nuosprendị konstatavęs, jog pirmosios instancijos teismas nepagrịstai atsisakẻ taikyti BK 81 straipsnio 2 dalies nuostatas nuteistojo A. S. atžvilgiu. Tokią išvadą apeliacinės instancijos teismas padare įvertinęs nuteistojo pateiktą psichologinio tyrimo išvadą bei jo padarytos nusikalstamos veikos aplinkybes (Šiaulių apygardos teismo $2011 \mathrm{~m}$. gegužès $5 \mathrm{~d}$. nuosprendis baudžiamojoje byloje Nr. 1A-48-135/2011).

44 Tuo atveju, jei jaunuolis nuo 18 iki 21 metų teismo pripažįstamas nepakankamai socialiai brandžiu, baudžiamosios materialinès teisès prasme jis laikomas nepilnamečiu. Ar nepakankamos socialinės brandos nustatymas turètų suponuoti ir specifinių procesinių nuostatų taikymą tokio asmens atžvilgiu, pasvarstysime tolesneje šio straipsnio dalyje.

45 Kuzavinis, K. Lotynų-lietuvių kalbų žodynas = Dictionarium Latino-Lituanicum. Vilnius: Mokslo ir enciklopedijų leidykla, 1996, p. 680. Cituota pagal Panomariovas, supra note 19.

46 Lietuvos civilinès teisès ir civilinio proceso doktrinoje prezumpcijų turinio ir reikšmès aiškinimas yra pakankamai vientisas ir nusistovejęs. Čia prezumpcija apibūdinama kaip sunorminta sveiko proto taisyklè, preziumuojanti egzistuojant tokị faktą, kurị ilgainiui patvirtina gyvenimo praktika. Teisinès prezumpcijos dar kitaip vadinamos aplinkybėmis, kurių nereikia įrodinèti, todèl ir jų paskirtis iš esmés siejama su ịrodinèjimo proceso supaprastinimu bei įrodinejjimo pareigos paskirstymu (plačiau žr.: Driukas, A.; Valančius, V. Civilinis procesas: teorija ir praktika. II tomas. Vilnius: Teisinès informacijos centras, 2006, p. 601; Laužikas, E.; Mikelènas, V.; Nekrošius, V. Civilinio proceso teisé. I tomas. Vilnius: Justitia, 2003, p. 435). 
tymas, paremtas socialiniais dėsningumais ${ }^{48}$. İrodinèjimo procese žodis ,pprezumpcija“ reiškia tai, kad tam tikra aplinkybe pradedant konkretų teisminị procesą pripažịstama egzistuojančia tol, kol šio proceso metu neįrodoma priešingai ${ }^{49}$.

Nepaisant to, kad mokslinèje literatūroje aktyviai diskutuojama dėl vienų ar kitų prezumpcijų rūšių išskyrimo, jų reikšmès ${ }^{50}$, šio straipsnio kontekste reikšmingos būtent teisinès nuginčijamos prezumpcijos. Šios prezumpcijų rūšies reikšmę analizuojamai tematikai lemia keletas aplinkybių. Pirma, nuginčijamos prezumpcijos, kurios yra vieno ar kito fakto egzistavimo prielaida, sudaro absoliučią teisinių prezumpcijų daugumą ${ }^{51}$; antra, iš esmès tik paneigiamos teisinès prezumpcijos gali būti taikomos baudžiamajame procese, kadangi absoliučios prezumpcijos yra nesuderinamos su tiesos paieškos ideja $^{52}$; trečia, galiausiai, šiame straipsnyje analizuojama pakankamos socialinès brandos prezumpcija priskirtina teisinėms nuginčijamoms prezumpcijoms. Taigi kokias funkcijas baudžiamajame procese atlieka teisinès nuginčijamos prezumpcijos?

Mokslinèje literatūroje galima aptikti nuomonių, kad visų teisinių nuginčijamų prezumpcijų, nepaisant to, ar jos taikomos civiliniame, ar baudžiamajame procese, pagrindinis tikslas yra vienokia ar kitokia forma supaprastinti įrodinėjimo procesą paskirstant ịrodinejjimo pareigą procese dalyvaujančioms šalims ${ }^{53}$. Su tokia nuomone, matyt, besąlygiškai būtų galima sutikti tik kalbant apie civiliniame procese galiojančias ir taikomas teisines prezumpcijas, kurios išties siejamos su įrodinejjimo procesu ir įrodinejjimo pareigos paskirstymu tarp šalių. Tačiau baudžiamajame procese galiojančias teisines prezumpcijas sieti vien tik su ịrodinejjimo procesu, jo supaprastinimu, vargu ar būtų teisinga. Antai, jau minètame moksliniame tyrime A. Panomariovas, be įtakos ịrodinèjimo procesui, išskyrè šias prezumpcijų funkcijas: valstybės socialinès politikos

48 Panomariovas, A., supra note, p. 7-8.

49 Dennis, I., supra note 19, p. 508-509.

50 Bene populiariausias yra prezumpcijų skirstymas pagal jų įtvirtinimo būdą į faktines prezumpcijas ir teisines prezumpcijas. Teisinemis laikomos tokios prezumpcijos, kurios yra ịtvirtintos teisès normose arba iš ju išvedamos, tuo tarpu faktinėmis - tokios prezumpcijos, kurios nèra ịtvirtintos teisès aktuose, o yra faktai, išvedami iš kitų jau nustatytų aplinkybių, dèl kurių nėra abejojama. Nors prezumpcijų skirstymas ị teisines ir faktines yra visuotinai priimtinas ir pakankamai dažnai pasitaikantis, vis dėlto susilaukia ir kritikos. Teigiama, kad savo galia faktinès prezumpcijos negali būti prilyginamos teisinèms prezumpcijoms, kadangi, visų pirma, jos neturi nieko bendra su teise, antra, jos, būdamos ne teisinėmis prezumpcijomis, nesukelia ir negali sukelti analogiškų teisinių padarinių, kokias sukelia teisinės prezumpcijos. Teisinės prezumpcijos, kurių svarba ir įtaka ịvairaus pobūdžio teisiniams santykiams yra nekvestionuojama, skirstomos ị nenuginčijamas (absoliučias) teisines prezumpcijas ir nuginčijamas (paneigiamas) teisines prezumpcijas. Galima sutikti su kai kurių autorių mintimis, jog nuginčijamų ir nenuginčijamų teisinių prezumpcijų reikšmės prilyginimas taip pat yra abejotinas, kadangi nenuginčijamos prezumpcijos iš esmès atlieka kitą vaidmenį nei nuginčijamos prezumpcijos - pirma, jos galioja pačios savaime, jų nereikia, o ir negalima nei patvirtinti, nei paneigti; antra, priešingai nei nuginčijamos prezumpcijos, jos neatlieka ịrodinèjimo pareigos paskirstymo funkcijos. Taigi jos galètų būti vadinamos tiesiog teisinèmis taisyklėmis (plačiau žr.: Allen, Ch. Evidence. 2007-2008. Seventh Edition. New York: Routledge - Cavendish, 2007, p. 31; Rinkevičius, J., supra note 19, p. 26; Emson, R. Evidence. Third Edition. Great Britain: Creative Print \& Design, 2006, p. 513; Panomariovas, A. Prezumpcija - formalioji įrodinèjimo priemonè, p. 28-29).

51 Terebeiza, Ž. Irodinejjimo našta ir jos paskirstymas civiliniame procese. Daktaro disertacija. Socialiniai mokslai (teisè 01S). Vilnius, 2009, p. 23.

52 Panomariovas, A. supra note 19.

53 Allen, Ch., supra note 50, p. 34; Dennis, I., supra note 19, p. 509. 
atspindejjimo; teisinio proceso optimizavimo, proceso dalyvių bei teismo laiko ir materialinių išteklių taupymo; teisinių santykių lankstumo, pastovumo ir aiškumo suteikimo bei išlaikymo ${ }^{54}$.

Kalbant apie įrodinėjimo pareigos paskirstymo funkciją, pažymėtina, kad kaip ir civiliniame procese, taip ir baudžiamajame, teisinès nuginčijamos prezumpcijos neabejotinai turi ịtakos įrodinejjimo procesui. Tačiau baudžiamajame procese prezumpcijos ịrodinèjimo pareigos paskirstymo funkciją igyvendina kitokiu būdu nei civiliniame procese. Kaip pavyzdi paanalizuokime vadinamają tėvystės prezumpciją (angl. presumption of legitimacy). Pagal šios prezumpcijos prasmę, civiliniame procese nustačius, kad kūdikis gimè praejjus atitinkamam laiko po teisètai sudarytos santuokos, preziumuojama, jog jis yra abiejų sutuoktinių vaikas. Ši prezumpcija gali būti paneigta tik vienai iš šalių, ginčijančiai šią aplinkybę, pateikus patikimų, preziumuojamą faktą paneigiančių duomenų. Tuo tarpu baudžiamajame procese, kuriame asmuo kaltinamas savo vaiko seksualiniu prievartavimu, jam ginčijant tèvystės faktą, būtent kaltinimo pusè turès pareigą patikrinti šią bent kiek pagrindo turinčią gynybinę versiją ${ }^{55}$. Toki prezumpcijų paneigimo pareigos skirtumą civiliniame ir baudžiamajame procesuose lemia pastarajame galiojanti nekaltumo prezumpcija, be kurios gilesnès turinio analizès nepavyktų atsakyti ị klausimą, kodèl ir kas turi pareigą paneigti baudžiamajame procese galiojančias prezumpcijas.

Nekaltumo prezumpcija yra vienas iš pagrindinių baudžiamojo proceso principų, žinomas bene visose, net ir autoritarinèse ${ }^{56}$, valstybèse ir yra ịtvirtintas daugelyje tarptautinių dokumentų - Tarptautinio pilietinių ir politinių teisių pakto ${ }^{57} 14$ straipsnio 2 dalyje, Europos žmogaus teisių ir pagrindinių laisvių apsaugos konvencijos ${ }^{58}$ 6 straipsnio 2 dalyje, Visuotinès žmogaus teisių deklaracijos ${ }^{59} 11$ straipsnio 1 dalyje; taip pat svarbiausiuose nacionaliniuose teisès aktuose, reglamentuojančiuose baudžiamaji procesą, - Lietuvos Respublikos Konstitucijoje ${ }^{60}$ bei Lietuvos Respublikos baudžiamojo proceso kodekse ${ }^{61}$ (toliau tekste - ir BPK). Šios prezumpcijos esmė ta, kad kiekvienas asmuo, kaltinamas nusikaltimo padarymu, laikomas nekaltu tol, kol jo kaltumas neirodytas teisès aktuose nustatyta tvarka, viešame teismo posėdyje, kuriame jam turi būti suteikiamos visos būtinos gynybos garantijos.

Nekaltumo prezumpcija, kaip formalaus teisètumo ir teisingumo baudžiamajame procese garantija ${ }^{62}$, formuluoja tris pagrindines teisines pozicijas: įrodyti kaltumą pri-

54 Panomariovas, A. supra note 19.

55 Allen, Ch., supra note 50, p. 35.

56 Pradel, J., supra note 21, p. 356.

57 Tarptautinis pilietinių ir politinių teisių paktas. Valstybès žinios. 2002, Nr. 77-3288.

58 Europos žmogaus teisių ir pagrindinių laisvių apsaugos konvencija. Valstybès žinios. 1995, Nr. 37-913; 2000, Nr. 96-3016.

59 Visuotinè žmogaus teisių deklaracija. Valstybès žinios. 2006, Nr. 68-2497.

60 Lietuvos Respublikos Konstitucija. Lietuvos Respublikos piliečių priimta 1992 m. spalio 25 d. referendume. Valstybès žinios. 1992, Nr. 33-1014.

61 Lietuvos Respublikos baudžiamojo proceso kodeksas (su pakeitimais ir papildymais). Valstybès žinios. 2002, Nr. 37-1341.

62 Spencer, M.; Spencer, J., supra note 19, p. 9. 
valo kaltintojas, draudžiama perkelti ịrodinėjimo pareigą baudžiamojon atsakomybèn traukiamam asmeniui ir (ar) jo gynejui bei tai, kad neįrodytas kaltumas, prilygsta ịrodytam nekaltumui ${ }^{63}$. Toliau aptarsime vieno iš nekaltumo prezumpcijos elementų - įrodinèjimo pareigos paskirstymo taisyklès igyvendinimo baudžiamajame procese aspektus.

Irodinejjimo pareiga (lot. onus probandi) buvo suformuluota dar romėnų teisinin$\mathrm{ku}^{64}$ ir šiandien yra suprantama kaip atitinkamų ịrodinejjimo subjektų užduotis rinkti, fiksuoti, tikrinti bei vertinti byloje surinktus duomenis (įrodymus), patvirtinančius arba paneigiančius aplinkybes, turinčias reikšmės bylai išspręsti teisingai ${ }^{65}$.

Lietuvos Respublikos Konstitucinis Teismas, pabrėždamas teisingo ir sąžiningo baudžiamojo proceso reikšmę, yra nurodęs, kad nekaltumo prezumpcija yra pamatinis teisingumo vykdymo baudžiamųjų bylų procese principas, viena iš svarbiausių žmogaus teisių ir laisvių garantijų ${ }^{66}$. Išanalizavus Konstitucinio Teismo jurisprudenciją galima daryti vienareikšmišką išvadą, kad, anot šio Teismo, įrodinejjimo pareiga baudžiamajame procese visais atvejais tenka būtent valstybiniam kaltintojui. Šis Teismas yra nurodęs, jog baudžiamajame procese galioja principas, pagal kurị teismas, prokuroras, tardytojas (pagal dabartinę BPK redakciją - ikiteisminio tyrimo pareigūnas - aut. pastaba) privalo imtis visų įstatyme numatytų priemonių, kad būtų visapusiškai ir objektyviai ištirtos bylos aplinkybès, tiek kaltinamaji kaltinančios, tiek ji teisinančios, taip pat jo atsakomybę lengvinančios ir sunkinančios aplinkybès. Tuo tarpu ịtariamasis ir kaltinamasis savo nekaltumo įrodinėti neprivalo ${ }^{67}$. Nepaisant tam tikrų pastarojo meto išimčių ${ }^{68}$, Lietuvos Aukščiausiasis Teismas taip pat yra pasisakęs, kad baudžiamajame procese įrodinejjimo pareiga, kaip ir pareiga paneigti kaltinamojo alibi, visais atvejais tenka kaltinimo pusei ${ }^{69}$.

63 Ashworth, A., supra note 19.

64 Jonaitis, M. Kai kurie šiuolaikinio civilinio proceso principai: nauji ilgaamžių idèjų vardai. Šiuolaikinės civilinio proceso teisès paskirtis. Tarptautinės mokslinès-praktinės konferencijos medžiaga. $2008 \mathrm{~m}$. birželio 5 ir 6 d. Vilnius: Mykolo Romerio universitetas, 2008, p. 144.

65 Jurka, R. Liudytojo procesiniu interesu apsauga baudžiamajame procese: problemos ir perspektyvos. Daktaro disertacija. Socialiniai mokslai (teisè 01S). Vilnius: Mykolo Romerio universitetas, 2008, p. 79.

66 Lietuvos Respublikos Konstitucinio Teismo nutarimas „Dėl Lietuvos Respublikos ginklų ir šaudmenų kontrolès įstatymo 19 straipsnio 8 dalies 9 punkto ir Lietuvos Respublikos Vyriausybės 1998 m. balandžio 10 d. nutarimo Nr. 436 „Dẻl ginklų ir šaudmenų apyvartą reglamentuojančių taisyklių patvirtinimo“ patvirtintų Medžioklinių ginklų apyvartos taisyklių 14.9 ir 57.2 punktų atitikties Lietuvos Respublikos Konstitucijai“. 2001 m. balandžio 12 d. Konstitucinio Teismo aktai. Kn. 3. (1999-2001). Vilnius: Lietuos Respublikos Konstitucinis Teismas, 2002.

67 Lietuvos Respublikos Konstitucinio Teismo nutarimas „Dèl Lietuvos Respublikos baudžiamojo proceso kodekso 58 straipsnio antrosios dalies 3 punkto atitikimo Lietuvos Respublikos Konstitucijai“. $1994 \mathrm{~m}$. lapkričio 18 d. Konstitucinio Teismo aktai. Kn.1. (1993-1995). Vilnius: Lietuvos Respublikos Konstitucinis Teismas, 1998.

68 Šios išimtys bus aptartos kitoje straipsnio dalyje.

69 Žr., pvz., Lietuvos Aukščiausiojo Teismo Baudžiamųjų bylų skyriaus teisèjų kolegijos 2006 m. sausio 17 d. nutartis baudžiamojoje byloje Nr. 2K-49/2006; Lietuvos Aukščiausiojo Teismo Baudžiamujų bylų skyriaus teisejjų kolegijos 2012 m. lapkričio 20 d. nutartis baudžiamojoje byloje Nr. 2K-562/2012; Lietuvos Aukščiausiojo Teismo Baudžiamųjų bylų skyriaus teisèjų kolegijos $2012 \mathrm{~m}$. gruodžio 4 d. nutartis baudžiamojoje byloje Nr. 2K-594/2012; Lietuvos Aukščiausiojo Teismo Baudžiamųų bylų skyriaus teisėjų kolegijos 2012 m. gruodžio 4 d. nutartis baudžiamojoje byloje Nr. 2K-619/2012 ir kt. 
Nors BPK nèra ịtvirtinta teisès normų, tiesiogiai reglamentuojančių įrodinèjimo pareigos paskirstymą, tačiau išvadą, jog šis ịstatymas nenumato galimybės perkelti ịrodinejjimo pareigos kaltinamajam ir (ar) jo gynejjui, galima padaryti sistemiškai analizuojant jo nuostatas. Štai BPK 2 straipsnyje nurodyta, jog būtent prokuroras ir ikiteisminio tyrimo ịstaigos kiekvienu atveju, kai paaiškèja nusikalstamos veikos požymių, privalo imtis visų priemonių, siekiant atlikti tyrimą ir atskleisti galimai padarytą nusikalstamą veiką. Pagal BPK 42 straipsni, valstybinis kaltinimas yra prokuroro veikla, kuria įrodinejama, kad nusikalstamos veikos padarymu kaltinamas asmuo yra kaltas, vadinasi, i̇rodinejjimo pareiga taip pat tenka kaltintojui.

Mokslinejje literatūroje iš esmès vieningai pripažįstama, kad klasikiniame baudžiamajame procese pareigą nustatyti tiesą turi tik viešieji asmenys - ikiteisminio tyrimo pareigūnas, prokuroras ir teisèjas. Pastarieji proceso dalyviai neturi teisètos galimybès priskirti savo pareigų i̇rodinejjimo procese kitiems asmenims - įtariamajam, kaltinamajam, nukentejusiajam, civiliniam ieškovui ir $\operatorname{pan}^{70}$. R. Jurkos teigimu, įrodinejjimo pareigą viešiesiems baudžiamojo proceso subjektams lemia proceso taisykles modeliuojanti legalumo ideja. Baudžiamojo proceso ịstatyme yra apibrezžtas baigtinis sąrašas procesą vykdančių dalyvių, todèl ir ịrodinejjimo pareiga priklauso ne kam kitam, o būtent šiems subjektams ${ }^{71}$. Be minètos legalumo idejjos, lemiančios įrodinejjimo pareigos priskyrimą viešiesiems baudžiamojo proceso subjektams, mokslinèje literatūroje taip pat galima aptikti nuomonių, jog baudžiamajame procese ịrodinejjimo pareiga privalo būti priskirta valstybinị kaltinimą palaikančiam subjektui dar ir todèl, kad gynybos ir kaltinimo šalių padètis, kalbant apie duomenų rinkimo bei pateikimo galimybes, yra akivaizdžiai nelygiavertè ${ }^{72}$. Iš pastarosios išplaukia ir kitas įrodinèjimo pareigos perkèlimo kaltinimo pusei tikslas - kaip įmanoma labiau sumažinti tikimybę nuteisti nekaltą asmenį, kadangi gynybos pusè neturi tokių procesinių, techninių, o dažnai ir materialinių galimybių pateikti įtikinamų nekaltumą patvirtinančių ar sudarančių prielaidas sušvelninti baudžiamąą atsakomybę duomenų, kokiomis disponuoja valstybės vardu veikianti kaltinimo pusè. Šiuo atveju verta prisiminti taiklią R. M. Dvorkino mintį, kad pagrindinè ir svarbiausia nekalto asmens teisè - tai teisè nebūti pripažintam kaltu ${ }^{73}$.

Kita vertus, sakyti, kad įrodinėjimo pareigos priskyrimas kaltinimo pusei yra absoliuti taisyklè, be išimčių, negalima. Antai D. Hameris, analizuodamas ịrodinèjimo pareigos priskyrimo kaltinamajam teorines galimybes, pažymi, jog, iš tiesų, nekalto asmens teisè nebūti nuteistam yra labai svarbi, tačiau nederètų pamiršti ir visuomenès teisès ị saugią būtį. Nekalto asmens nuteisimas yra tokia pati blogybe kaip ir kaltojo išteisinimas, todèl tam tikrais atvejais, anot šio autoriaus, kaltumo prezumpcijos įtvirtinimas ir įrodinėjimo pareigos perkèlimas kaltinamajam yra pateisinamas ${ }^{74}$. Tokioms

70 Panomariovas, A.; Ramanauskas, R. Slaptumas - tiesos baudžiamajame procese nustatymo priemonè. Jurisprudencija. 2005, 75 (67): 50-57.

71 Jurka, R., supra note 65, p. 79.

72 Ashworth, A., supra note 19, p. 259.

73 Dworkin, R. M. Principle, Policy and Procedure. Crime, Proof and Punishment. London: Butterworths, 1981, p. 68.

74 Hamer, D. A Dynamic Reconstruction of the Presumption of Innocence. Oxford Journal of Legal Studies. 2011, 31 (2): 417-435. 
idejjoms atsirasti stimulą davė pasekmių teorijos (angl. consequentialism theory) šalininkai, pasak kurių, tam tikrais atvejais visai visuomenei priimtinas rezultatas - nusikaltimų skaičiaus sumažinimas ir jų ištyrimo pagreitinimas, yra pakankamas pagrindas pateisinti ịrodinèjimo pareigos sumažinimą kaltinimo pusei ir jos padidinimą konkrečiam individui, padariusiam nusikaltimą ${ }^{75}$. Tikètina, jog vadovaujantis tokiomis idejomis, tam tikrose valstybėse ir buvo ịtvirtintos nekaltumo prezumpcijai priešingos kaltumo prezumpcijos, ịpareigojančius būtent kaltinamajj pateikti ịtikinamų ịrodymų, patvirtinančių jo nekaltumą ${ }^{76}$. Vis dèlto tokia teorija ir ją pagrindžiančios idèjos yra gana drąsios, todèl neabejotinai susilaukia ir kritikos. Pirmiau minètoms mintims oponuojantys autoriai tvirtina, jog jokie visuomenès interesai negali pateisinti nekalto asmens nuteisimo, kurio tikimybę ịstatymiškai įtvirtinta nekaltumo prezumpcijos priešingybè tik padidintų ${ }^{77}$. Mokslininkai, besivadovaudami socialinio kontrakto (angl. social contract) teoretikų idejjomis, pabrěžia dar ir tai, kad, nustatant balansą tarp siekio išvengti nekaltojo asmens nuteisimo ir kaltojo asmens išteisinimo, prioritetas vis dèlto turi būti suteikiamas pirmajam tikslui, kadangi nekaltai nuteisto asmens moralinè, asmeninè žala yra didesné blogybė nei žala, kurią galimai (bet - ne būtinai - aut. pasta$b a)$ patirtų visuomenè dèl neteisingo išteisinimo ${ }^{78}$. Akcentuojama ir tai, kad neteisingas nuteisimas šiuo atveju reiškia ne tik nepagrįstą kaltės nustatymą, bet ir ikiteisminio bei teisminio proceso metu padarytus pažeidimus, suvaržiusius įtariamojo (kaltinamojo) teises ${ }^{79}$.

Šiame kontekste pažymètina, kad pastaruoju metu Lietuvoje taip pat galima ižzvelgti tendenciją susiaurinti iš nekaltumo prezumpcijos išplaukiančios įrodinėjimo pareigos priskyrimo viešiesiems baudžiamojo proceso subjektams taisyklę tiek ịsta-

75 Spencer, M.; Spencer, J., supra note 19, p. 10.

76 Pavyzdžiui, pagal Prancūzijoje galiojančius teisès aktus, preziumuojama, kad asmuo, sulaikytas disponuojant narkotinėmis ar psichotropinėmis medžiagomis, yra kaltas padaręs šių medžiagų kontrabandą. Kaltintojas neturi pareigos ịrodinèti asmens, padariusio tokį nusikaltimą, kaltès. Tuo tarpu kaltinamasis turi įrodyti buvus force major ir jam nežinojus apie gabenamų daiktų neteisètą kilmę (Harris, D. J., et al. Law of the European Convention on Human Rigths. Second Edition. United States: Oxford University Press, 2009, p. 302). EŽTT byloje Salabiaku v. France konstatavo, jog tokia Prancūzijos teisès aktuose ịtvirtinta nekaltumo prezumpcijos išimtis nesudaro pagrindo išvadai, kad yra pažeidžiamas Konvencijos 6 straipsnio 2 dalies nuostatos. EŽTT šioje byloje, be kita ko, pažymèjo, kad Konvencijos 6 straipsnio 2 dalyje ịtvirtinta nekaltumo prezumpcija savaime neapriboja valstybėms galimybės nacionaliniuose įstatymuose ịtvirtinti kaltinamajam nepalankių teisès ar fakto prezumpcijų. Tačiau šalys, prieš įtvirtindamos tokias prezumpcijas, turi įvertinti, ar jos yra proporcingos kaltinamojo teisių suvaržymui (plačiau žr.: Cox, H, J. Criminal Evidence Handbook. Second Edition. Canada: Canada Law Book Inc., 1991, p. 7-9).

77 Žr., pvz., Stumer, A. The Presumption of Innocence: Evidential and Human Rights Perspectives. Oxford: Hart Publishing, 2010, p. 155.

78 Jackson, J. D.; Summers, S. J. The Internationalisation of Criminal Evidence. Beyond the Common Law and Civil Law Traditions. United Kingdom: Cambridge University Press, 2012, p. 200.

79 Dennis, I. The Right to Confront Witnesses: Meanings, Myths and Human Rights. The Criminal Law Review. 2010, 4: 255-274, p. 259. 
tymų leidybos srityje ${ }^{80}$, tiek teismų praktikoje $\mathrm{e}^{81}$. Šios aplinkybės patvirtina mokslinėje doktrinoje išreiškiamą poziciją, kad apie baudžiamojo proceso principų sistemą (taip pat ir konkretaus principo turinị - aut. pastaba) galima kalbėti tik kaip apie nuolat kintančią ir atsinaujinančią, priklausomai nuo ịvairių veiksnių ${ }^{82}$. Vis dẻlto, atsižvelgdami i šio straipsnio objektą, nesileisime i gilesnę diskusiją apie tai, ar yra pateisinamas ịrodinejjimo pareigos perkèlimas kaltinamajam tam tikrų kategorijų bylose idant būtų apsaugotas viešasis interesas, tačiau neabejotina, kad šis klausimas vertas mokslinès analizès ir pagrindimo.

Taigi, įvertinus anksčiau išdèstytas mintis, galima daryti išvadą, jog, nepaisant tam tikrų išimčių, nėra teorinių galimybių perkelti įrodinèjimo pareigos kaltinamajam. Vadinasi, pareiga paneigti baudžiamajame procese galiojančias teisines prezumpcijas, nepaisant to, kam ši prezumpcija yra naudinga - ar palengvina ikiteisminio tyrimo subjektų darbą (pavyzdžiui, pakaltinamumo prezumpcija), ar saugo įtariamojo, kaltina-

80 Antai, 2010 m. gruodžio 2 d. ịstatymu Lietuvos Respublikos baudžiamasis kodeksas papildytas nauja norma, kriminalizuojančia neteisètą praturtėjimą. Šio nusikaltimo turinị sudaro turto, kuris negali būti pagrịstas teisètomis priemonėmis, turèjimas. Iš esmès tai reiškia, kad legalių pajamų nepakankamumas ir asmens nesugebejjimas paaiškinti praturtẻjimo šaltinio lemia išvadą, kad turtas igytas iš neišaiškintos nusikalstamos veikos (Fedosiuk, O. Baudžiamųju įstatymų prieš neteisètas pajamas ir korupciją leidyba: tarp gerų siekių ir legitimumo. Jurisprudencija. 2012, 19 (3): 1215-1233). Tuo pačiu įstatymu naujai ịtvirtintas ir BK $72^{3}$ straipsnis, reglamentuojantis išplèstinị turto konfiskavimą. Pagal šio straipsnio nuostatas, išplèstinis turto konfiskavimas taikomos esant trims sąlygoms, iš kurių viena yra ta, kad baudžiamojo proceso metu kaltininkas negali pagrịsti turimo turto ịsigijimo teisètumo. Tokios naujovès Baudžiamajame ịstatyme susilaukia tiek praktikų, tiek mokslininkų kritikos (žr., pvz., Fedosiuk, O. Baudžiamujų ịstatymų prieš neteisetas pajamas ir korupciją leidyba: tarp gerų siekių ir legitimumo, supra note, p. 1215-1233; Piesliakas, V. Nusikalstamu būdu gautų pajamų konfiskavimas Lietuvos baudžiamojoje teisèje: siekiai ir realybè. Jurisprudencija. 2011, 18(2): 675-688). Vertinant tokios kritikos pagrįstumą, derètu atkreipti dèmesị i tai, kad panašios nuostatos dèl išplèstinio turto konfiskavimo 1992 metais buvo ịtvirtintos ir Italijos baudžiamuosiuose įstatymuose. Tačiau Italijos Respublikos Konstitucinis Teismas tokias nuostatas pripažino antikonstituciškomis ir nesuderinamomis su nekaltumo prezumpcijos principu (Spencer, J. R.; Juy-Birmann, R.; Perrodet, A., et al. European Criminal Procedures. Edited by Mireille Delmas - Marty and J. R. Spencer. Cambridge: Cambridge University Press, 2005, p. 599).

81 Lietuvos Aukščiausiasis Teismas pastaraisiais metais formuoja teismų praktiką, pagal kurią tam tikras aplinkybes, susijusias su neteisètai pasisavinto ar iššvaistyto turto panaudojimu, pateikdamas atitinkamus objektyvius duomenis, irodyti turi pareigą kaltinamasis ir (ar) jo gynejjas,,$-<$ Todèl kaltininko tvirtinimai dèl pinigu panaudojimo ịmonès reikmèms turi būti paremti konkrečiais duomenimis <...>“. Ir nors šiose nutartyse nurodoma, jog pirmiau minèta nuostata „<... nereiškia, kad ịrodinèjimo pareiga perkeliama kaltininkui ir pažeidžiama nekaltumo prezumpcija <..."“, vis dèlto kyla tam tikrų abejonių dèl tokios formuojamos teismų praktikos suderinimo su draudimu perkelti ịrodinèjimo pareigą kaltinamajam (žr., pvz., Lietuvos Aukščiausiojo Teismo Baudžiamųjų bylų skyriaus teisèjų kolegijos $2012 \mathrm{~m}$. spalio 9 d. nutartis baudžiamojoje byloje Nr. 2K-471/2012; Lietuvos Aukščiausiojo Teismo Baudžiamujų bylų skyriaus plenarinès sesijos 2012 m. gegužès 8 d. nutartis baudžiamojoje byloje Nr. 2K-P-78/2012). Kita vertus, šiuo atveju deretų atkreipti dèmesị ị tai, kad Europos Žmogaus Teisių Teismas ne vienoje byloje yra išreiškęs poziciją, kad tam tikrais atvejais, nepažeidžiant proporcingumo principo, tam tikrų aplinkybių ịrodymo pareigos perkèlimas pats savaime nereiškia Konvencijos 6 straipsnio pažeidimo, jei nacionaliniai teismai užtikrino tinkamą teisès ị gynybą įgyvendinimą (pavyzdžiui, žr.: Pham Hoang v. France, 25 September 1992, § 33 Series A no. 243, Salabiaku v. France, 7 October 1988, § 12-15, John Murray v. United Kingdom, 29 January 1996, § 47, Heany and McGuinness v. Ireland, 21 December 2000, § 45-52).

82 Plačiau žr.: Ažubalytė, R. Baudžiamojo proceso principai: teisès spragų šalinimas. Lietuvos Respublikos Baudžiamojo proceso kodeksui - 10 metų. Vilnius: Vilniaus universitetas Teisès fakultetas, Lietuvos Aukščiausiasis Teismas, 2012, p. 13-34. 
mojo teisę ị sąžiningą procesą (pavyzdžiui, nekaltumo prezumpcija), turi ne kas kitas, o būtent kaltinimo pusé. Šiuo atveju pritartina profesoriui I. Dennis, anot kurio, ne viena baudžiamajame procese galiojanti teisinè prezumpcija negali veikti tokiu būdu, kad jos paneigimo ar ịrodymo pareiga tektų ittariamajam (kaltinamajam) ${ }^{83}$. Vadinasi, ir pakankamos socialinès brandos prezumpciją paneigti pareigą turi ne kas kitas, o būtent viešieji baudžiamojo proceso subjektai. Ypatingai turint omenyje tai, kad tuo atveju, jei teismas nuspręstų, jog teisiamasis nèra visiškai socialiai brandus, taigi, kaip ir nepilnametis neturi visiško procesinio veiksnumo ${ }^{84}$, jam tenka pareiga pateikti pakankamai tai patvirtinančių duomenų. Akivaizdu, jog tokia situacija yra nesuderinama su tarptautiniuose teisès aktuose įtvirtintais ịpareigojimais nepilnamečių baudžiamaji procesą vykdyti taip, kad šis būtų orientuotas ị papildomą nepilnamečio teisių apsaugą ir jo gerovès užtikrinimą ${ }^{85}$.

\section{Nepakankamos socialinès brandos įrodinëjimas ikiteisminio tyrimo metu - prielaida užtikrinti teisingą nepilnamečiu baudžiamąji procesą}

Taigi, atsakant ị pirmiau užduotą klausimą, darytina išvada, kad šiuo metu susiformavusi teismų praktika paneigiant pakankamos socialinės brandos prezumpciją yra nesuderinama su baudžiamajame procese galiojančia įrodinėjimo pareigos paskirstymo taisykle. Manytina, kad tokią ydingai besiklostančią teismų praktiką būtina koreguoti taikant kompleksines priemones. Visų pirma atkreiptinas dėmesys ị tai, kad Baudžiamojo įstatymo nuostatos dèl galimybès taikyti specifinę nepilnamečių baudžiamosios atsakomybès formą jauniems pilnamečiams nèra suderintos su Baudžiamojo proceso îstatymo nuostatomis. Šiuo metu galiojančiame BPK teisiškai svarbi yra tik pilnametystès riba: tik jaunesniems nei 18 metų asmenims, dalyvaujantiems baudžiamajame procese, taikomos specifinės proceso taisyklès. Tokiu būdu pripažįstama, kad asmenys iki 18 metu neturi pakankamo procesinio veiksnumo, todėl jie negali visiškai teisingai suvokti bylos aplinkybių, pareigūnų priimamų sprendimų, taip pat suvokti tiek savo veiksmų, tiek ir su savo teisètais interesais susijusių veiksmų reikšmės ir pasekmių ${ }^{86}$. Todèl BPK įtvirtintos tam tikros papildomos procesinès garantijos, taikomos įtariamiesiems (kaltinamiesiems), baudžiamojo proceso metu nesulaukusiems 18 metų amžiaus. Kita vertus, literatūroje nepakankamas procesinis veiksnumas yra siejamas ne tik su asmens amžiumi, bet ir su jo fizine bei psichine branda ${ }^{87}$. Teigiama, kad nepilnamečių (taip pat ir jiems prilygintų asmenų) nepakankamą procesinị veiksnumą lemia kogni-

\footnotetext{
83 Dennis, I., supra note 19, p. 512.

84 Ažubalytè, R., supra note 12, p. 74.

85 Jungtinių Tautų standartinès minimalios nepilnamečių teisenos ịgyvendinimo taisyklès (Pekino gairès), supra note 3 .

86 Ažubalytè, R; Jurgaitis, R.; Zajančkauskienè, supra note 12, p. 228, 229.

87 Ibid.
} 
tyvinis ir emocinis nebrandumas ${ }^{88}$, kuris, neabejotina, taip pat turi reikšmès suvokiant jauno pilnamečio atžvilgiu vykdomą baudžiamaji procesą, su juo atliekamų veiksmų reikšmę ir galimas pasekmes. Todẻl lieka neaišku, kodėl Baudžiamajame įstatyme specifinès baudžiamosios atsakomybès formos taikymas yra siejamas su dviem kriterijais amžiumi ir socialine branda, o tuo tarpu specifinių, nepilnamečiams skirtų procesinių taisyklių taikymą lemia išimtinai tik asmens amžius, nesuteikiant galimybių jų taikyti jaunam pilnamečiui ir tokiu būdu individualizuoti baudžiamaji procesą, atsižvelgiant ị asmens psichines, fizines bei socialines savybes.

Literatūroje ne kartą pabrèžta, kad kalbant apie nepilnamečių baudžiamosios atsakomybès ypatumus, nederètų pamiršti ir baudžiamojo proceso eigos: kaip vyksta tyrimas, kokios institucijos jị atlieka, kokios procesinès prievartos priemonès taikomos, kaip pasireiškia žmogiškasis faktorius ${ }^{89}$. Šios aplinkybès svarbios siekiant išvengti, kad pats baudžiamasis procesas nepadarytų žalos nevisiškai brandžiam asmeniui. Taip pat nurodoma, kad nepilnamečiams numatyti proceso taisyklių ypatumai igyja ne mažiau svarbią reikšmę teisingumo sistemos poveikio nepilnamečiams struktūroje, nei, baigus procesą, pritaikyta specifinè baudžiamosios atsakomybès forma arba atleidimas nuo $\operatorname{jos}^{90}$. I ši aspektą atkreiptas dèmesys ir tarptautiniuose teisès aktuose, kuriuose rekomenduojama valstybėms numatyti galimybes, kad asmenims iki 21 metų, teisèjui nusprendus, jog pagal brandą ir atsakingumą jie neprilygsta suaugusiesiems, būtų taikomos nepilnamečiams numatytos procesinès taisyklès bei intervencija ${ }^{91}$. Panašios nuostatos kartojamos ir Europos Tarybos Ministrų Komiteto rekomendacijoje CM/Rec(2008)11 valstybėms narėms dèl Europos nepilnamečiams teisès pažeidèjams taikomų sankcijų ir poveikio priemonių taisyklių ${ }^{92}$. Šios rekomendacijos 17 ir 21.2 punktuose pabrèžiama, kad nusikaltęs jaunas pilnametis yra bet kuris 18-21 metų asmuo, ịtariamas nusikalstamos veikos padarymu ar ją padaręs, kuris, esant tinkamoms sąlygoms, gali būti laikomas nepilnamečiu ir su juo atitinkamai elgiamasi kaip su nepilnamečiu.

Apibendrinant pirmiau aptartas aplinkybes, pritartina R. Ažubalytès nuomonei, jog Baudžiamojo proceso įstatyme būtina įtvirtinti nuostatą, kad, atsižvelgus ị ịtariamųjų (kaltinamųjų), kuriems baudžiamojo proceso metu suejjo 18 metų, socialinę brandą,

88 Sellers, B. G.; Arrigo, B. A. Adolscent Transfer, Developmental Maturity, and Adjudicative Competence: an Ethical and Justice Policy Inquiry. The Journal of Criminal Law \& Criminology. 2009, 99 (2): 440.

89 Pakštaitis, L. Nepilnamečių baudžiamosios atsakomybės reglamentavimo bei taikymo problemos. Jurisprudencija. 2007, 8 (98): 13-19.

90 Ažubalytè, R., supra note 12, p. 71.

91 Recommendation No. R (2003) 20 of the Committee of Ministers to member states concerning new ways of dealing with juvenile delinquency and the role of juvenile justice. Adopted by the Committee of Ministers on 24 September 2003, at the 853 meeting of the Ministers' Deputies. Cituota pagal Nepilnamečiu baudžiamosios atsakomybés ypatumų taikymo 18-20 metu jaunuoliams Lietuvoje tyrimas, supra note 8.

92 Recommendation CM/Rec(2008)11 of the Committee of Ministers to member states on the European Rules for juvenile offenders subject to sanctions or measures (Adopted by the Committee of Ministers on 5 November 2008 at the 1040th meeting of the Ministers' Deputies). Cituota pagal Nepilnamečiu baudžiamosios atsakomybés ypatumu taikymo 18-20 metu jaunuoliams Lietuvoje tyrimas, supra note 8. 
jie baudžiamojo proceso metu gali būti laikomi nepilnamečiais ${ }^{93}$, taigi, jiems gali būti taikomos specifinès, nepilnamečiams skirtos baudžiamojo proceso normos ${ }^{94}$.

Pripažįstant, kad socialinès brandos nustatymas yra reikšmingas taikant ne tik materialines, bet ir procesines normas bei siekiant užtikrinti visapusišką jaunuolio apsaugą nuo neigiamų baudžiamojo proceso padarinių ir žalą keliančios aplinkos, manytina, kad aplinkybès, susijusios su BK 81 straipsnio 2 dalies nuostatų taikymu, turi būti įrodinejjamos ne teisminio nagrinèjimo stadijoje, o pačioje pradinejje - ikiteisminio tyrimo - stadijoje. Atliekant procesinius veiksmus su ịtariamuoju nuo 18 iki 21 metu amžiaus ir kilus pagrịstų abejonių dèl jo nepakankamos socialinès brandos, ikiteisminị tyrimą vykdantys subjektai turètų imtis visų i̇manomų priemonių šioms abejonėms pašalinti - surinkti tokị asmenị charakterizuojančius duomenis, taip pat duomenis apie fizinę bei psichinę sveikatos būklę, apklausti šeimos narius, mokytojus ir kitus asmenis, galinčius suteikti vertingos informacijos; įvertinus šiuos duomenis, spręsti klausimą dèl specialisto pasitelkimo. Tuo atveju, jei surinkti duomenys leistų pagrịstai manyti, kad įtariamojo socialinè branda nèra pakankama, tokiam asmeniui de facto turètų būti užtikrinama galimybė naudotis visomis specifinèmis, nepilnamečiams skirtomis papildomomis procesinėmis garantijomis. Pažymėtina, kad tokia praktika atitiktų ir kitose užsienio valstybėse, kuriose jau kurị laiką akcentuojama vadinamosios vaiko gerovès doktrinos (angl. child welfare doctrine) reikšmè baudžiamajame procese, praktiką. Antai, Didžiojoje Britanijoje sulaikius jauną asmenị, dèl kurio pilnametystès kyla bent menkiausios abejonès, jam nedelsiant užtikrinama galimybė naudotis visomis nepilnamečiams skirtomis papildomomis procesinėmis garantijomis ${ }^{95}$.

Neneigiant teismo diskrecinès teisès konkrečioje byloje spręsti klausimą dẻl BK 81 straipsnio 2 dalies taikymo jauno pilnamečio atžvilgiu, svarstytinas klausimas ir dèl galimybès BPK ịtvirtinti nuostatą, pagal kurią dar ikiteisminio tyrimo metu surinkus pakankamai objektyvių duomenų dèl ịtariamojo nepakankamos socialinės brandos, prokuroras turètų galimybę kreiptis ị ikiteisminio tyrimo teisèją prašydamas nutartimi pripažinti tokị ịtariamaji jaunuolị nepilnamečiu ir nuo šio momento jis igytų ne tik faktinę, bet ir juridinę teisę naudotis visomis jam suteikiamomis papildomomis procesinèmis garantijomis.

93 Ažubalytè, R., supra note 12, p. 73.

94 Šiuo atveju derètų atkreipti dėmesị ị teigiamą Vokietijos praktiką sprendžiant jaunų pilnamečių baudžiamosios atsakomybès klausimus ir taikant specifines proceso taisykles. Ši valstybè viena pirmujų Europoje savo baudžiamuosiuose įstatymuose išskyrė jaunų pilnamečių grupę bei iki šiol plačiausiai taiko įstatyme jiems numatytus baudžiamosios atsakomybės ypatumus. Čia galimybė taikyti nepilnamečiams skirtas Baudžiamojo įstatymo nuostatas teismo iniciatyva apsvarstoma kiekvienu atveju nagrinèjant baudžiamają bylą, kurioje kaltinamas jaunas nepilnametis. Specifinès Baudžiamojo įstatymo nuostatos teisme aiškinamos plačiai, sudarant galimybes jauniems pilnamečiams taikyti ir specifines baudžiamojo proceso taisykles. Plačiau žr.: Nepilnamečiu baudžiamosios atsakomybès ypatumu taikymo 18-20 metu jaunuoliams Lietuvoje tyrimas, supra note 8.

95 Hannibal, M.; Mountford, L. Criminal Litigation. 2006-2007. Great Britain: Oxford University Press, 2007, p. 493-494. 


\section{Išvados}

1. Lietuvos Respublikos baudžiamajame įstatyme ịtvirtinta galimybė jaunuoliui nuo 18 iki 21 metų, kurio socialinè branda prilygsta nepilnamečiui, taikyti specifinę nepilnamečių baudžiamosios atsakomybès formą, doktrinoje vertintina teigiamai, tačiau praktikoje taikoma itin vangiai dèl keleto priežasčių, taip pat ir dèl to, kad pagal šiuo metu susiformavusią teisėsaugos institucijų praktiką, pareiga pateikti pakankamos socialinès brandos prezumpciją paneigiančius duomenis paprastai tenka gynybos šaliai.

2. Baudžiamajame procese ịrodinèjimo pareiga, su tam tikromis išimtimis, atitinkančiomis proporcingumo principą ir viešaji interesą, priklauso viešiesiems baudžiamojo proceso subjektams, o šios pareigos perkèlimas įtariamajam (kaltinamajam) ir (ar) jo gynèjui gali būti pakankamas pagrindas konstatuoti, kad įrodinejjimo procesas, o kartu ir visas baudžiamasis procesas, konkrečioje baudžiamojoje byloje buvo vykdomas nesąžiningai. Todèl empirinio tyrimo metu nustatyta vyraujanti teisėsaugos instituciju praktika perkeliant pakankamos socialinès brandos prezumpcijos paneigimą gynybos šaliai vertintina kaip neatitinkanti nekaltumo prezumpcijos.

3. Ydingai besiklostanti praktika paneigiant pakankamos socialinès brandos prezumpciją koreguotina tiek įstatymų leidybos srityje - suderinant Baudžiamojo įstatymo ir Baudžiamojo proceso ịstatymo nuostatas, tiek praktiškai - formuojant praktiką, pagal kurią nepakankamos socialinès brandos prezumpcijos paneigimas vyktų ikiteisminio tyrimo stadijoje. Tokia praktika leistų pasiekti keletą tikslų: pirma, tokiu būdu kaltinamasis, nepaisant to, kokią gynybos formą yra pasirinkęs - gintis pačiam ar pasinaudoti teise turèti gynejją, nebūtų priverstas teisminio nagrinèjimo metu iškelti savo nepakankamos socialinès brandos klausimo bei pateikti įtikinamų šią aplinkybę pagrindžiančių duomenų; antra, nustačius, kad kaltinamasis negali būti pripažistamas pakankamos socialinès brandos, taigi, ir neturintis visiško procesinio veiksnumo, jam būtų sudaryta galimybė pasinaudoti specifinėmis Baudžiamojo proceso nuostatomis (BPK 53 str., 51 str. 1 d., 186 str., 138 str., 127 str. 2 d. ir kt.) jau nuo ikiteisminio tyrimo stadijos; trečia, kartu su kitais bylai išspręsti teisingai būtinais duomenis teismui būtų pateikiami ir duomenys, apibūdinantys kaltinamo jauno pilnamečio socialinę brandą, tokiu būdu užtikrinant visapusišką, išsamų ir spartesnį baudžiamosios bylos išnagrinèjimą teisme; ketvirta, ikiteisminio tyrimo metu išsamiai surinkti duomenys apie kaltinamojo socialinę brandą sudarytų prielaidas teismams dažniau taikyti BK 81 straipsnio 2 dalies nuostatas.

\section{Literatūra}

Abramavičius, A., et al. Lietuvos Respublikos baudžiamojo kodekso komentaras. Bendroji dalis. Vilnius: Teisinès informacijos centras, 2004.
Allen, Ch. Evidence. 2007-2008. Seventh Edition. New York: Routledge - Cavendish, 2007. 
Ashworth, A. Four Threats to the Presumption of Innocence. The International Journal of Evidence \& Proof. 2006, 10: 241-279.

Ažubalytė, R. Baudžiamojo proceso, kuriame dalyvauja nepilnamečiai, teisinès ir faktinès diferenciacijos prielaidos ir iš jų kylantys reikalavimai. Sąžiningas baudžiamasis procesas. Probleminiai aspektai. Vilnius: Industrus, 2009.

Ažubalytė, R. Baudžiamojo proceso principai: teisès spragu šalinimas. Lietuvos Respublikos Baudžiamojo proceso kodeksui - 10 metu. Vilnius: Vilniaus universitetas Teisès fakultetas, Lietuvos Aukščiausiasis Teismas, 2012.

Ažubalytė, R; Jurgaitis, R.; Zajančkauskienė, J. Specifinès baudžiamojo proceso rüšys. Vadovèlis. Vilnius: Mykolo Romerio universitetas, 2011.

Barbera, Messegue and Jabardo v. Spain, no. 10588/83, 10589/83, 10590/83.

Cipriani, D. Children's Rights and the Minimum Age of Criminal Responsibility: A Global Perspective. United Kingdom: Ashgate Publishing, 2009.

Cox, H. J. Criminal Evidence Handbook. Second Edition. Canada: Canada Law Book Inc., 1991.

Dennis, I. The Right to Confront Witnesses: Meanings, Myths and Human Rights. The Criminal Law Review. 2010, 4: 255-274.

Dennis, I. The Law of Evidence. Third Edition. London: Sweet \& Maxwell, 2007.

Drakšienè, A. Pakaltinamumas kaip nepilnamečių baudžiamosios atsakomybės prielaida. Teisé. 2006, 58: 54-70.

Drakšienè, A.; Drakšas, R. Nepilnamečiu baudžiamoji atsakomybè. Vadovèlis. Antroji pataisyta ir papildyta laida. Vilnius: Eugrimas, 2008.

Driukas, A.; Valančius, V. Civilinis procesas: teorija ir praktika. II tomas. Vilnius: Teisinès informacijos centras, 2006.

Dworkin, R. M. Principle, Policy and Procedure. Crime, Proof and Punishment. London: Butterworths, 1981.
Elliott, C. Criminal Responsibility and Children: A New Defence Required to Acknowledge the Absence of Capacity and Choice. Journal of Criminal Law. 2011, 75: 289-308.

Emson, R. Evidence. Third Edition. Great Britain: Creative Print \& Design, 2006.

Europos žmogaus teisių ir pagrindinių laisvių apsaugos konvencija. Valstybès žinios. 1995, Nr. 37-913; 2000, Nr. 96-3016.

Fedosiuk, O. Baudžiamųjų ịstatymų prieš neteisètas pajamas ir korupciją leidyba: tarp gerų siekių ir legitimumo. Jurisprudencija. 2012, 19 (3): 1215-1233.

Goda, G. Nekaltumo prezumpcija: ịtvirtinimas Lietuvos teisèje ir kai kurie turinio aspektai. Teisè. 2002, 44: 42-52.

Hamer, D. A Dynamic Reconstruction of the Presumption of Innocence. Oxford Journal of Legal Studies. 2011, 31(2): 417-435.

Hannibal, M.; Mountford, L. Criminal Litigation. 2006-2007. Great Britain: Oxford University Press, 2007.

Heany and McGuinness v. Ireland, 21 December 2000, § 45-52.

Jackson, J. D.; Summers, S. J. The Internationalisation of Criminal Evidence. Beyond the Common Law and Civil Law Traditions. United Kingdom: Cambridge University Press, 2012.

John Murray v. United Kingdom, 29 January 1996, § 47.

Jonaitis, M. Kai kurie šiuolaikinio civilinio proceso principai: nauji ilgaamžių idèjų vardai. Šiuolaikinès civilinio proceso teisès paskirtis. Tarptautinès mokslinès-praktinès konferencijos medžiaga. $2008 \mathrm{~m}$. birželio 5 ir 6 d. Vilnius: Mykolo Romerio universitetas, 2008.

Joniškio rajono apylinkès teismo $2011 \mathrm{~m}$. lapkričio 18 d. nuosprendis baudžiamojoje byloje Nr. 1-13-645/2011.

Jovaišas, K. Nekaltumo prezumpcija: žinomo principo nežinomi aspektai. Teisés problemos. 2004, 4 (46): 83-99.

Jungtinių Tautų standartinès minimalios nepilnamečių atžvilgiu vykdomo teisingumo 
taisyklès (Pekino taisyklès) [interaktyvus]. [Žiūrèta 2011-09-25]. <http://www.nplc.lt/ nj/Dokumentai/Uzs_teis_aktai/Pekinotaisykles\%20red.htm>.

Jurka, R. Liudytojo procesiniu interesu apsauga baudžiamajame procese: problemos ir perspektyvos. Daktaro disertacija. Socialiniai mokslai (teisè 01S). Vilnius, 2008.

Kauno apygardos teismo 2010 m. gruodžio 7 d. nuosprendis baudžiamojoje byloje Nr. 1A759-397/10.

Kauno apygardos teismo 2009 m. gruodžio 23 d. nuosprendis baudžiamojoje byloje Nr. 1-76-290/09.

Kauno apygardos teismo $2011 \mathrm{~m}$. balandžio 22 d. nutartis baudžiamojoje byloje Nr. 1A276-317/2011.

Kauno apygardos teismo 2010 m. gruodžio 7 d. nuosprendis baudžiamojoje byloje Nr. 1A759-397/2010.

Kauno miesto apylinkès teismo $2011 \mathrm{~m}$. balandžio 15 d. nuosprendis baudžiamojoje byloje Nr. 1-129-651/2011.

Klaipėdos apygardos teismo 2009 m. gegužès 28 d. nutartis baudžiamojoje byloje Nr. 1A248-458/2009.

Klaipėdos apygardos teismo 2009 m. gegužès 28 d. nutartis baudžiamojoje byloje Nr. 1A248-458/2009.

Klaipėdos apygardos teismo $2012 \mathrm{~m}$. balandžio 23 d. nuosprendis baudžiamojoje byloje Nr. 1A-99-557/2009.

Kuzavinis, K. Lotynų-lietuvių kalbų žodynas = Dictionarium Latino-Lituanicum. Vilnius: Mokslo ir enciklopedijų leidykla, 1996.

Laužikas, E.; Mikelènas, V.; Nekrošius, V. Civilinio proceso teise. I tomas. Vilnius: Justitia, 2003.

Lietuvos Respublikos Konstitucija. Lietuvos Respublikos piliečių priimta 1992 m. spalio 25 d. referendume. Valstybès žinios. 1992, Nr. 33-1014.

Lietuvos Respublikos baudžiamasis kodeksas (su vėlesniais pakeitimais ir papildymais). Valstybès žinios. 2000, Nr. 89-274.

Lietuvos Respublikos baudžiamojo proceso kodeksas (su vėlesniais pakeitimais ir papildymais). Valstybès žinios. 2002, 37-1341.
Lietuvos Respublikos Konstitucinio Teismo nutarimas „Dèl Lietuvos Respublikos ginklų ir šaudmenų kontrolès ịstatymo 19 straipsnio 8 dalies 9 punkto ir Lietuvos Respublikos Vyriausybės $1998 \mathrm{~m}$. balandžio $10 \mathrm{~d}$. nutarimo Nr. 436 „Dél ginklų ir šaudmenų apyvartą reglamentuojančių taisyklių patvirtinimo“ patvirtintų Medžioklinių ginklų apyvartos taisyklių 14.9 ir 57.2 punktų atitikties Lietuvos Respublikos Konstitucijai“. $2001 \mathrm{~m}$. balandžio 12 d. Konstitucinio Teismo aktai. Kn. 3. (1999-2001). Vilnius: Lietuos Respublikos Konstitucinis Teismas, 2002.

Lietuvos Respublikos Konstitucinio Teismo nutarimas „Dėl Lietuvos Respublikos baudžiamojo proceso kodekso 58 straipsnio antrosios dalies 3 punkto atitikimo Lietuvos Respublikos Konstitucijai“. 1994 m. lapkričio 18 d. Konstitucinio Teismo aktai. Kn.1. (1993-1995). Vilnius: Lietuvos Respublikos Konstitucinis Teismas, 1998.

Lietuvos Aukščiausiojo Teismo Baudžiamųjų bylų skyriaus teisejjų kolegijos $2011 \mathrm{~m}$. birželio $30 \mathrm{~d}$. nutartis baudžiamojoje byloje Nr. 2K-325/2011.

Lietuvos Aukščiausiojo Teismo Baudžiamųjų bylų skyriaus teisèjų kolegijos $2011 \mathrm{~m}$. gruodžio $27 \mathrm{~d}$. nutartis baudžiamojoje byloje Nr. 2K-629/2011.

Lietuvos Aukščiausiojo teismo Baudžiamųjų bylų skyriaus teisèjų kolegijos 2009 m. vasario $3 \mathrm{~d}$. nutartis baudžiamojoje byloje Nr. 2K-39/2009.

Lietuvos Aukščiausiojo Teismo Baudžiamųjų bylų skyriaus teisejjų kolegijos $2008 \mathrm{~m}$. gruodžio 22 d. nutartis baudžiamojoje byloje Nr. 2K-435/2008.

Lietuvos Aukščiausiojo Teismo Baudžiamųjų bylų skyriaus teisèjų kolegijos $2006 \mathrm{~m}$. birželio $13 \mathrm{~d}$. nutartis baudžiamojoje byloje Nr. 2K-418/2006.

Lietuvos Aukščiausiojo Teismo Baudžiamųjų bylų skyriaus teisèjų kolegijos $2005 \mathrm{~m}$. kovo $8 \mathrm{~d}$. nutartis baudžiamojoje byloje $2 \mathrm{~K}$ $67 / 2005$. 
Lietuvos Aukščiausiojo Teismo Baudžiamųjų bylų skyriaus teisèjų kolegijos $2006 \mathrm{~m}$. vasario $7 \mathrm{~d}$. nutartis baudžiamojoje byloje Nr. 2K-142/2006.

Lietuvos Aukščiausiojo Teismo Baudžiamųų bylų skyriaus teisèjų kolegijos $2006 \mathrm{~m}$. balandžio $25 \mathrm{~d}$. nutartis baudžiamojoje byloje Nr. 2K-266/2006.

Lietuvos Aukščiausiojo Teismo Baudžiamųjų bylų skyriaus teisèjų kolegijos $2006 \mathrm{~m}$. sausio $17 \mathrm{~d}$. nutartis baudžiamojoje byloje Nr. 2K-49/2006.

Lietuvos Aukščiausiojo Teismo Baudžiamųjų bylų skyriaus teisèjų kolegijos $2012 \mathrm{~m}$. lapkričio 20 d. nutartis baudžiamojoje byloje Nr. 2K-562/2012.

Lietuvos Aukščiausiojo Teismo Baudžiamųjų bylų skyriaus teisejjų kolegijos $2012 \mathrm{~m}$. gruodžio $4 \mathrm{~d}$. nutartis baudžiamojoje byloje Nr. 2K-594/2012.

Lietuvos Aukščiausiojo Teismo Baudžiamųjų bylų skyriaus teisèjų kolegijos $2012 \mathrm{~m}$. gruodžio 4 d. nutartis baudžiamojoje byloje Nr. 2K-619/2012.

Lietuvos Aukščiausiojo Teismo Baudžiamųjų bylų skyriaus teisèjų kolegijos $2012 \mathrm{~m}$. spalio 9 d. nutartis baudžiamojoje byloje Nr. 2K-471/2012.

Lietuvos Aukščiausiojo Teismo Baudžiamųjų bylų skyriaus plenarinès sesijos $2012 \mathrm{~m}$. gegužěs $8 \mathrm{~d}$. nutartis baudžiamojoje byloje Nr. 2K-P-78/2012.

Lietuvos apeliacinio teismo Baudžiamųų bylų skyriaus teisèjų kolegijos $2011 \mathrm{~m}$. liepos 15 d. nutartis baudžiamojoje byloje Nr. 1A$110 / 2011$.

Lietuvos apeliacinio teismo Baudžiamujų bylų skyriaus teisèjų kolegijos $2012 \mathrm{~m}$. balandžio 27 d. nutartis baudžiamojoje byloje Nr. 1A216/2012.

Mathews, B. P. Australian Laws Ascribing Criminal Responsibility to Children: the Implications of an Internal Critique, Postmodern Insights, and A Deconstructive Exploration. Doctor of Philosophy Disertation. Queensland University of Technology, Faculty of Law, 2001.
Nepilnamečių baudžiamosios atsakomybès ypatumų taikymo 18-20 metų jaunuoliams Lietuvoje tyrimas. Tyrimo vadove Laura Ūselè. Teisès institutas, 2010 [interaktyvus]. [žiūrèta 2012-12-28]. < www.teise.org/data/ Nepilnameciu-baudziamoji-atsakomybe. pdf $>$.

Pakštaitis, L. Nepilnamečių baudžiamosios atsakomybès reglamentavimo bei taikymo problemos. Jurisprudencija. 2007, 8 (98): 13-19.

Panomariovas, A. Prezumpcija-formalioji ịrodinejimo priemone (atiduota leidybai).

Panomariovas, A.; Ramanauskas, R. Slaptumas - tiesos baudžiamajame procese nustatymo priemonè. Jurisprudencija. 2005, 75 (67): 50-57.

Pham Hoang v. France, 25 September 1992, $\S 33$ Series A no. 243.

Piesliakas, V. Nusikalstamu būdu gautų pajamų konfiskavimas Lietuvos baudžiamojoje teisèje: siekiai ir realybè. Jurisprudencija. 2011, 18 (2): 675-688.

Pradel, J. Lyginamoji baudžiamoji teisé. Vilnius: Eugrimas, 2001.

Recommendation No. R (2003) 20 of the Committee of Ministers to member states concerning new ways of dealing with juvenile delinquency and the role of juvenile justice. Adopted by the Committee of Ministers on 24 September 2003, at the 853 meeting of the Ministers' Deputies [interaktyvus]. [žiūrèta 2012-12-27]. <https://wcd.coe.int/ ViewDoc.jsp?id=70063>. Recommendation $\mathrm{CM} / \operatorname{Rec}(2008) 11$ of the Committee of Ministers to member states on the European Rules for juvenile offenders subject to sanctions or measures. Adopted by the Committee of Ministers on 5 November 2008 at the 1040th meeting of the Ministers' Deputies [interaktyvus]. [žiūrèta 201207-14]. < https://wcd.coe.int/ViewDoc. jsp?id $=1367113 \&$ Site $=\mathrm{CM}>$.

Recommendation No. R (87) 20 of the Committee of Ministers to member states on social reaction to juvenile delinquency. Adopted by the Committee of Ministers 
on 17 September 1987, at the 410 meeting of the Ministers' Deputies [interaktyvus]. [žiūrèta 2012-12-27]. <https://wcd.coe.int/ com.instranet.InstraServlet? command $=\mathrm{com}$. instranet.CmdBlobGet\&InstranetImage $=6$ 08029\&SecMode $=1 \&$ DocId $=694290 \&$ Usa $\mathrm{ge}=2>$.

Recommendation No. R (2003) 20 of the Committee of Ministers to member states concerning new ways of dealing with juvenile delinquency and the role of juvenile justice. Adopted by the Committee of Ministers on 24 September 2003, at the 853 meeting of the Ministers' Deputies [interaktyvus]. [žiūrèta 2012-12-27]. <https://wcd.coe.int/ ViewDoc.jsp?id=70063>.

Rinkevičius, J. Procesiniai įrodinèjimo baudžiamojoje byloje pagrindai. Vilnius: Vilniaus universiteto leidykla, 1990.

Sakalauskas, G. Nepilnamečių baudžiamosios atsakomybės ypatumų, numatytų naujajame Lietuvos Respublikos baudžiamajame kodekse, igyvendinimo problemos. Teisé. 2001, 41: 148-162.

Sakalauskas, G.; Jatkevičius, A. Tarptautiniai dokumentai, reglamentuojantys vaiku ir jaunimo baudžiamają atsakomybę. Teisés problemos. 2000, 3-4: 29-39.

Salabiaku v. France, 7 October 1988, § 12-15. Sellers, B. G.; Arrigo, B. A. Adolscent Transfer, Developmental Maturity, and Adjudicative Competence: an Ethical and Justice Policy Inquiry. The Journal of Criminal Law \& Criminology. 2009, 99 (20).

Spencer, J. R.; Juy-Birmann, R.; Perrodet, A., et al. European Criminal Procedures. Edited by Mireille Delmas - Marty and J. R. Spencer. Cambridge: Cambridge University Press, 2005.

Spencer, M.; Spencer, J. Evidence. Fourth Edition. Great Britain: Ashford Colour Press, 2005.
Stumer, A. The Presumption of Innocence: Evidential and Human Rights Perspectives. Oxford: Hart Publishing, 2010.

Šiaulių apygardos teismo 2011 m. gegužès 5 d. nuosprendis baudžiamojoje byloje Nr. 1A48-135/2011.

Šakių rajono apylinkès teismo $2008 \mathrm{~m}$. spalio 27 d. nuosprendis baudžiamojoje byloje Nr. 1-64-634/2008.

Tarptautinis pilietinių ir politinių teisių paktas. Valstybès žinios. 2002, Nr. 77-3288.

Terebeiza, Ž. Irrodinejjimo našta ir jos paskirstymas civiliniame procese. Daktaro disertacija. Socialiniai mokslai (teisè 01S). Vilnius, 2009.

Utenos rajono apylinkès teismo $2011 \mathrm{~m}$. kovo 1 d. nuosprendis baudžiamojoje byloje Nr. 1-23-373/2011.

Ūselè, L. Socialinès brandos sampratos ir turinio problema sprendžiant jaunų pilnamečių (18-20 metų) baudžiamosios atsakomybès klausimą. Teisè. 2011, 78: 182-195.

Ūselè, L. Jaunų pilnamečių (18-20 metų) socialinè branda - nepilnamečių baudžiamosios atsakomybės ypatumų jiems taikymo veiksnys. Teisés problemos. 2010, 2 (68): 58-89.

Vilniaus apygardos teismo $2007 \mathrm{~m}$. gruodžio 3 d. nuosprendis baudžiamojoje byloje Nr. 1-208/2007.

Vilniaus apygardos teismo $2010 \mathrm{~m}$. sausio $25 \mathrm{~d}$. nuosprendis baudžiamojoje byloje Nr. 1A$123 / 2010$.

Vilniaus apygardos teismo $2007 \mathrm{~m}$. gruodžio 3 d. nuosprendis baudžiamojoje byloje Nr. 1-208/2007.

Vilniaus rajono apylinkès teismo $2012 \mathrm{~m}$. kovo $7 \mathrm{~d}$. nuosprendis baudžiamojoje byloje Nr. 1-58-269/2012.

Visuotinè žmogaus teisių deklaracija. Valstybès žinios. 2006, Nr. 68-2497. 


\title{
PROBLEMATIC ASPECTS OF PRESUMPTION OF INNOCENCE WHILE ESTABLISHING INSUFFICIENT SOCIAL MATURITY OF A YOUNG ADULT
}

\author{
Dovilè Gaidelytė
}

Mykolas Romeris University, Lithuania

Summary. The article analyses the context regarding the presumption of sufficient social maturity regulated by the norms of criminal procedure.

Legal norms foresee the possibility to apply the peculiarities of juvenile criminal responsibility to young adults (18-20 years), when their social maturity is equal to juvenile's maturity. However, the researches conducted by the author of the article as well as the Law Institute revealed the fact that the provisions of the criminal law, which are considered to be modern and highly evaluated by the scientists, are rarely applied in practice. Moreover, the accused person and (or) his counsel for the defence avail themselves of a duty to deny the presumption of sufficient social maturity. Taking into consideration the principle of presumption of innocence and the rule regarding sharing of burden of proof, the author of the article drew a conclusion that the present denial mechanism of sufficient social maturity does not only contradict to the presumption of innocence, but also is not in compliance with the purposes and requirements established for the juveniles in the criminal procedure.

The article tries to show that the issue regarding sufficient social maturity should be examined in the pre-trial investigation, but not in the trial itself. In such a case, some goals are possible to be achieved. Firstly, the legal interests and rights of a young adult participating in the criminal procedure could be more secured. Secondly, the principles of comprehensibility and economy of the criminal procedure could be implemented.

Keywords: criminal procedure, social maturity, presumption, burden of proof, juvenile, young adult.

Dovilè Gaidelytė, Mykolo Romerio universiteto Teisès fakulteto Baudžiamosios teisès ir proceso instituto doktorantè. Mokslinių tyrimų kryptys: baudžiamasis procesas, nepilnamečių baudžiamojo proceso dalyvių teisių apsauga.

Dovilè Gaidelytė, Mykolas Romeris University, Faculty of Law, Institute of Criminal Law and Procedure, Doctoral Student. Research interests: criminal procedure, the protection of juvenile rights in the criminal process. 